\title{
“LA GENTE PIDE QUE ESTÉN LOS SENEGALESES": NEGOCIACIONES EN UNA CIUDAD TURÍSTICA DE LA PATAGONIA
}

\author{
María Luz Espiro ${ }^{1}$
}

\section{Introducción}

Para comprender las particularidades de las trayectorias laborales de migrantes de origen senegalés en Argentina -problemática central de mi investigación doctoral ${ }^{2}$ es necesario ubicarlas en las circunstancias espaciales en las que sus protagonistas desarrollan sus biografías y despliegan dichos itinerarios (Muñiz Terra, 2012; Roberti, 2017). Por ello, en este artículo analizo las dinámicas que ocurren en un espacio de destino estacional para estos migrantes, la ciudad patagónica de Puerto Madryn, con un doble propósito. En primer lugar, me interesa presentarla desde un punto de vista sociohistórico y demográfico, para situar la migración senegalesa en el devenir de su configuración societal; en segundo lugar, me propongo analizar los aspectos de esta ciudad que inciden de manera particular en la conformación de las trayectorias laborales de estos migrantes. En este sentido, prestaré especial atención tanto a ciertas características desde las que se imagina esta urbe y se interviene en ella, como a los imaginarios que circulan entre algunos sectores de su población respecto de las y los senegaleses y su trabajo. Asimismo, abordaré algunas representaciones de los migrantes sobre estos sectores, que conforman las estrategias para la consecución de sus objetivos laborales.

Me interesa profundizar en estos aspectos de la dimensión urbana, ya que permiten reflexionar sobre cuestiones centrales que coloca el fenómeno de la creciente migración senegalesa transnacional en esta parte del mundo. En particular, repensar las políticas de la diferenciación y alteridad en las ciudades latinoamericanas contemporáneas; así como las nuevas conexiones interurbanas generadas por las prácticas de circulación de estos actores, que configuran nuevos espacios regionales

\footnotetext{
${ }^{1}$ Universidad Nacional de La Plata, Argentina. Email: mluzespiro@gmail.com ORCID id: https://orcid.org/0000-0001-8122-6981

${ }^{2}$ Este artículo se desprende de mi tesis doctoral “Trayectorias laborales de migrantes senegaleses en La Plata y Puerto Madryn: una etnofotografía de los imaginarios y prácticas en torno al trabajo (20122018)", Universidad Nacional de La Plata, 2019. Dirigida por la Dra. Bernarda Zubrzycki (UNLP) y la Dra. Ana Luiza Carvalho da Rocha (UFRGS). Financiada por becas de posgrado UNLP y por proyectos de investigación acreditados (PICT 2012/ 0074, PIP- CONICET 0018, PID 11/N827).
} 
transfronterizos $^{3}$. En este trabajo me centraré mayormente en la primera de esas cuestiones, puesto que los espacios urbanos -fundamentalmente la calle- son el locus de muchas de las prácticas laborales de migrantes senegaleses y el foco de constantes disputas entre ellos y diversos sectores de la sociedad receptora, sobre todo las élites dominantes (Van Dijk, 2006). Como veremos, estas disputas condensan las significaciones por el espacio urbano mismo, que desde las estructuras políticas y desde los sectores hegemónicos de la cultura se intentan anclar, pero que desde su agencia los migrantes buscan dotar de sentidos alternativos y reapropiar. De esta manera procuran acceder al espacio urbano, a la ciudad, construyendo su territorio, afirmando sus posiciones y negociando sus estrategias laborales y sus identidades en ámbitos de alto flujo de personas, de producción y consumo, y fuerte carga simbólica para los habitantes de la ciudad de Puerto Madryn.

Sigo a Segura (2015: 35) cuando afirma que:

Una ciudad no se reduce a sus características materiales: edificaciones, plazas y parques, calles, avenidas y autopistas, infraestructura comunicacional y de servicios. Una ciudad involucra también la multiplicidad de discursos, imágenes, representaciones y relatos que elaboran quienes viven en ella y que les posibilitan establecer vínculos con el espacio urbano (...) representaciones que, además, tienen efectos en los modos en que se transforma materialmente la ciudad.

Entonces, entre la ciudad y los procesos sociales hay un vínculo dialéctico de influencia y conformación mutua. Mientras las características de la ciudad dan forma a la vida social, los procesos sociales moldean el territorio, pero no de cualquier modo.

La configuración de la ciudad, en tanto escenario principal de la vida en las sociedades modernas y, por ello, fuente de conflictos es, de algún modo, resultado del ejercicio de diferentes grupos por la ocupación del espacio, de sus formas de oposición a otros y de las relaciones de fuerza que son capaces de ejercer ante situaciones específicas (...). Pleno de fisuras y condicionantes de etapas pasadas, el territorio de la ciudad está marcado por los intereses - muchas veces contradictorios entre sí- de los grupos dominantes; pero también, por conquistas sectoriales y formas de resistencia popular (Perelman, 2017: 11).

La investigación que nutre este artículo se basa en una etnografía con migrantes de origen senegalés en Puerto Madryn entre 2015 y 2018 ${ }^{4}$, y en menor medida en otras ciudades costeras de Chubut (provincia de la Patagonia central argentina) como el balneario Playa Unión, Trelew y Comodoro Rivadavia. Realicé entrevistas, conversaciones y observaciones participantes con senegaleses y senegalesas en sus

\footnotetext{
${ }^{3}$ Para profundizar sobre el circuito regional transfronterizo que conecta la Patagonia argentina con el sur de Brasil ver Espiro (2017).

${ }^{4}$ Esta ciudad es una de las que conforman la etnografía multisituada que llevé adelante para mi investigación doctoral, que incluye además otras ciudades argentinas, ciudades del sur de Brasil y de Senegal (principalmente de la Cuenca del Maní, zona centro-oeste del país, de donde provienen los protagonistas de esta investigación).
} 
espacios de trabajo y domésticos, también entrevisté a población receptora y llevé a cabo una revisión de artículos periodísticos de un medio local, siguiendo un criterio de exhaustividad (Courtine, 1981, en Caggiano, 2005). Una estrategia teóricometodológica central fue la producción de imágenes como parte del estudio sensible de la complejidad humana. Dado que el conocimiento etnográfico se produce en experiencias que involucran todos los sentidos de las personas participantes (Rocha, 1995; Clifford, 1999; Guber, 2014; Rocha y Eckert, 2015), durante mi trabajo de campo las imágenes fotográficas tuvieron un lugar central para crear narrativas visuales en una etnofotografía (Rocha y Eckert, 2013), es decir, un proceso de construcción de pensamiento conceptual antropológico en el marco de una investigación etnográfica con imágenes fotográficas. Para ello, a partir de un corpus de imágenes de distintas fuentes (aquí incluyo fotografías de noticias de diarios locales y otras tomadas por mí ${ }^{5}$ de modo consentido por mis interlocutores durante el trabajo de campo ${ }^{6}$ ), se montaron los mosaicos que forman las narrativas visuales, complementadas en una intertextualidad con los demás materiales etnográficos.

Finalmente, quiero enfatizar que la decisión de profundizar en las dinámicas que involucran a migrantes senegaleses en la ciudad de Puerto Madryn, apunta a contribuir a la descentralización de los abordajes sobre procesos migratorios concentrados en las capitales latinoamericanas. Busco traer al debate una ciudad intermedia en plena expansión demográfica que se ubica entre las más pobladas de la Patagonia argentina, porque ofrece matices sobre las negociaciones en las complejas ciudades contemporáneas. En dicha ciudad el aumento de la heterogeneidad étnico-nacionalcultural, debido a la diversificación de los flujos migratorios internacionales y las interacciones que se suscitan en estos contextos, presenta sus especificidades. Pero también evidencia continuidades con procesos similares en los grandes centros urbanos latinoamericanos. En particular, los procesos de hipervisibilización de la diferencia propios de las políticas globales sobre multiculturalismo (Grimson, 2006) que se dan en las grandes metrópolis, encuentran su correlato en estas ciudades en expansión, donde

\footnotetext{
${ }^{5}$ Pero en mi tesis trabajo también con fotografías de campo producidas por mis interlocutores y otras de acervo de sus redes sociales.

${ }^{6}$ La puesta a disposición del material producido de modo consentido a lo largo de esta etnografía, es decir, la restitución de la imagen del otro, constituyó una premisa fundamental desde el inicio de esta relación etnográfica (Rocha y Eckert, 2014). Al tener en cuenta la matriz comunicativa propia de los protagonistas de esta investigación, la oralidad y la visualidad tienen mucha mayor relevancia que la escritura. Por ello, la devolución visual del producto de esta etnografía fue bien recibidas al constituir, por un lado, un contrapunto a las representaciones visuales estereotipadas que circulan en la prensa local y con las cuales no se identifican, y por el otro, al conformar una memoria de y para ellos.
} 
se observa la emergencia de relatos xenófobos y racistas sobre migrantes senegaleses. Siguiendo a Teun Van Dijk (2006: 17) el racismo constituye:

[...] un sistema de dominación y de desigualdad social (...) el abuso de poder de un grupo sobre otro, y está representado por dos sistemas interrelacionados de prácticas sociales y sociocognitivas cotidianas, es decir, por varias formas de discriminación, marginación, exclusión o problematización por un lado y por creencias, actitudes e ideologías prejuiciosas y estereotipadas por otro (...) El discurso es la práctica social que relaciona estos dos campos de racismo y la práctica social casi exclusiva de las élites simbólicas y las instituciones.

Se trata de narrativas propias de la matriz de interlocución nacional dominante según la cual "la invisibilización histórica de los negros en la Argentina es condición de posibilidad para que la percepción de estas nuevas presencias propenda al sobredimensionamiento y la extrañeza" (Morales, 2010: 142), generando procesos de segregación e inserción desigual para dichos migrantes en la ciudad de Puerto Madryn, quienes despliegan estrategias para readecuar sus proyectos allí.

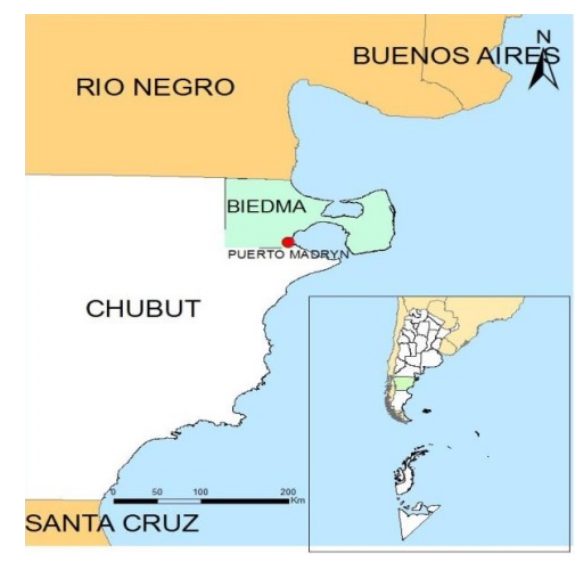

Puerto Madryn. Departamento de Biedma, Provincia de Chubut (Argentina).

Fuente: Kaminker (2016)

\section{Aproximación a la ciudad de Puerto Madryn}

Puerto Madryn es una ciudad intermedia en expansión (Kaminker, 2015; Ferrari, 2018) ubicada a orillas del mar Atlántico sobre el Golfo Nuevo, al noroeste de la provincia de Chubut, en la Patagonia central argentina ${ }^{7}$. Tres elementos característicos inciden en las dinámicas socioeconómicas de la ciudad: un clima árido de estepa, un puerto natural de aguas profundas y la cercanía a la entrada de la Península Valdés, reserva natural desde 1983 y declarada "Patrimonio Natural de la Humanidad" por

la UNESCO en 1999.

Los principales recursos que dinamizan las actividades económicas locales son el aluminio, el pórfido, la pesca y el turismo, todos ligados a los mercados internacionales y por ende, muy sensibles a sus variaciones y a las crisis económicas (Kaminker, 2016).

La historia de su fundación contribuyó a crear un imaginario particular de la ciudad, asociado a un pequeño contingente de galeses que partieron de Liverpool

\footnotetext{
${ }^{7}$ En términos geográficos, cuenta con una superficie de $360 \mathrm{~km}^{2}$, se ubica a $42^{\circ}$ de latitud sur y $65^{\circ}$ de longitud oeste y a $1.325 \mathrm{~km}$ al sur de la Ciudad Autónoma de Buenos Aires.
} 
(Inglaterra) en mayo de 1865 y desembarcaron dos meses después del navío "Mimosa" en estas costas patagónicas. Dichos colonos estaban resueltos a fundar un país propio, cuyos emblemas principales giraban en torno a la preservación de la lengua, la religión, la laboriosidad y la convivencia pacífica con los habitantes previos del lugar ${ }^{8}$. Pero finalmente, fueron incorporados al territorio nacional en formación bajo las leyes argentinas. Entonces, "el desembarco", tal como se nombra este episodio que tiene su feriado provincial el 28 de julio, constituye "un hito fundacional de la 'gesta' de los colonos galeses, pero también un mito central de la identidad provincial de Chubut en general y de Puerto Madryn en particular" (Kaminker, 2014: 6), en aparente convivencia con los pueblos mapuche-tehuelche pre-existentes, pero en verdadera tensión con el lugar que ocupan en la narrativa identitaria.

Sin embargo, el proyecto colonizador galés no tuvo asidero en lo que hoy es Puerto Madryn inmediatamente después de la llegada de los galeses. Recursos necesarios como el agua dulce y tierras cultivables se ubicaban 80 kilómetros más al sur, en el Valle Inferior del Río Chubut donde se originó el poblado de Rawson (hoy ciudad capital provincial, cuyo balneario es Playa Unión). Esto impulsó la introducción del ferrocarril hacia 1886, para conectar esa y otras localidades del Valle con el puerto natural de Madryn. Sin embargo, las altísimas tarifas impuestas por la compañía ferroviaria inglesa para los transportes regionales de productos importados y locales, acabó favoreciendo un asentamiento permanente en Madryn y la formación del poblado $^{9}$ (Dumrauf, 1993 en Kaminker, 2016).

En estas dinámicas -sucintamente explicadas- se apoyan los sentidos que construyen la narrativa identitaria dominante de la sociedad de Puerto Madryn, centrada en "la convivencia pacífica, la perseverancia, la tenacidad, el espíritu aventurero, el idealismo, el respeto a la diversidad, la no discriminación, e inclusive la tradición" (Kaminker, 2014: 14) y “todas las instancias oficiales están cargadas de esta mitología” (Ibíd.: 18).

\footnotetext{
${ }^{8}$ Parte de esta narrativa conocida como "gesta galesa" refiere al "encuentro de dos mundos" representado por los galeses recién llegados y los tehuelches, originarios habitantes del territorio.

${ }^{9}$ La antigüedad del mismo coincide entonces con la construcción de la obra ferroviaria. De hecho, la ciudad recibe el nombre de Madryn por Sir Love Jones Parry un barón nacido en la ciudad homónima en Gales, quien proyectó inicialmente la construcción del ferrocarril aquí. La actividad ferroviaria no es un elemento anecdótico, sino que hasta su desmantelamiento en 1961 marcó el ritmo del crecimiento urbano de Puerto Madryn, porque con sucesivos nombres, fue la empresa que la concesionaba la que controló el mercado de tierras e inmobiliario (Kaminker, 2016).
} 
Cabe destacar que según el censo de 1947 la población de la ciudad sumaba solamente unos 3.441 habitantes y aunque con la construcción del gasoducto patagónico aumentara escasamente esta cifra, no superaría los 7.000 habitantes hasta la década de 1970, cuando fue seleccionada para el emplazamiento de la planta de aluminio primario más grande de Latinoamérica. Con la migración sin precedentes atraída por las fuentes de trabajo en torno a esta industria, se inició una expansión demográfica y una transformación urbana continua y conflictiva (Kaminker, 2016).

Actualmente Puerto Madryn se erige como la ciudad cabecera del Departamento de Biedma, siendo la tercera ciudad más poblada de la provincia de Chubut y una de las diez más numerosas de la Patagonia (Sassone, González y Matossian, 2011; Kaminker, 2016). Se trata de un espacio de transformación acelerada, tanto física, como social y demográficamente, que en las últimas décadas multiplicó su población de 6.183 habitantes en 1970 a 81.995 en 2010, de acuerdo al último Censo Nacional de Población, Hogares y Viviendas (INDEC, 2012). Este crecimiento exponencial está asociado a dos momentos: el primero hacia 1970, con el desarrollo industrial impulsado por la mencionada instalación de la empresa Aluminio Argentino S.A.I.C (ALUAR) y empresas de pórfido y pesqueras; el segundo hacia 1990, con el sector turístico y de servicios (coincidiendo con la declaración de la UNESCO), posicionándose como el nuevo motor de crecimiento de la ciudad, que emergería como el centro turístico más importante de Chubut, de proyección internacional. En palabras de Kaminker (2015: 1): “desde esta década, se comenzó a vislumbrar una tensión entre dos proyectos o modelos de ciudad, uno industrial y otro de servicios y turismo", propios ambos de un urbanismo neoliberal hegemónico productor de desigualdad social. Entre otras problemáticas, cabe mencionar el acceso desigual entre los diversos sectores a recursos como el suelo urbano y la vivienda (Ferrari, 2018), los servicios básicos y el espacio público.

Como se puede inferir, el componente migratorio resulta una variable fundamental en este contexto, que atraviesa ambos modelos y explica también este proceso demográfico acelerado que experimenta la ciudad de Puerto Madryn. De carácter interna e internacional, la migración es atraída por la oferta laboral, buscando aprovechar las oportunidades de trabajo en las diversas industrias y el turismo, y en menor medida asociada a un imaginario de "calidad de vida". Sassone, González y Matossian (2011) indican que ya para el 2001 la población extranjera de Puerto Madryn era de 3.966 personas representada en los cinco países limítrofes de Argentina (Bolivia, 
Brasil, Chile, Paraguay y Uruguay) mostrando un caso de "diversidad migratoria", en tanto ninguna de las nacionalidades de origen superaba el 50\% del total de la población limítrofe. Entre las más numerosas están la inmigración boliviana $(48,31 \%)$ y la chilena $(43,87 \%)$, estas "representan el $91 \%$ de la población proveniente de países limítrofes y el 5,6\% del total de la población de la ciudad. Entre los países de origen no limítrofes con Argentina se destacan los migrantes de España (245), Italia (145) y Francia (80), representando el 51,2\% de este grupo sin alcanzar al 1\% del total de la población" (Kaminker, 2016: 86). Esta realidad permitiría afirmar que Puerto Madryn es un espacio donde los colectivos migratorios tienen una creciente visibilidad (Ibíd.).

Si bien Sassone, González y Matossian (2011: 12) plantean que Puerto Madryn "es un claro ejemplo de ciudad patagónica, una ciudad nueva, una ciudad de pioneros, una ciudad de tehuelches y mapuches, una ciudad de inmigrantes del mundo lejano como de orígenes próximos latinoamericanos, una ciudad de argentinos $\mathrm{NyC}$ (nacidos y criados) y VyQ (venidos y quedados)", las interacciones entre todos estos actores lejos están de articularse pacíficamente. En palabras de Kaminker (2016: 13) esto se debe a "los mecanismos de exclusión que se dan en una ciudad intermedia en franca expansión, donde lo socio-económico, las redes familiares, étnicas y hasta el racismo parecen entrar
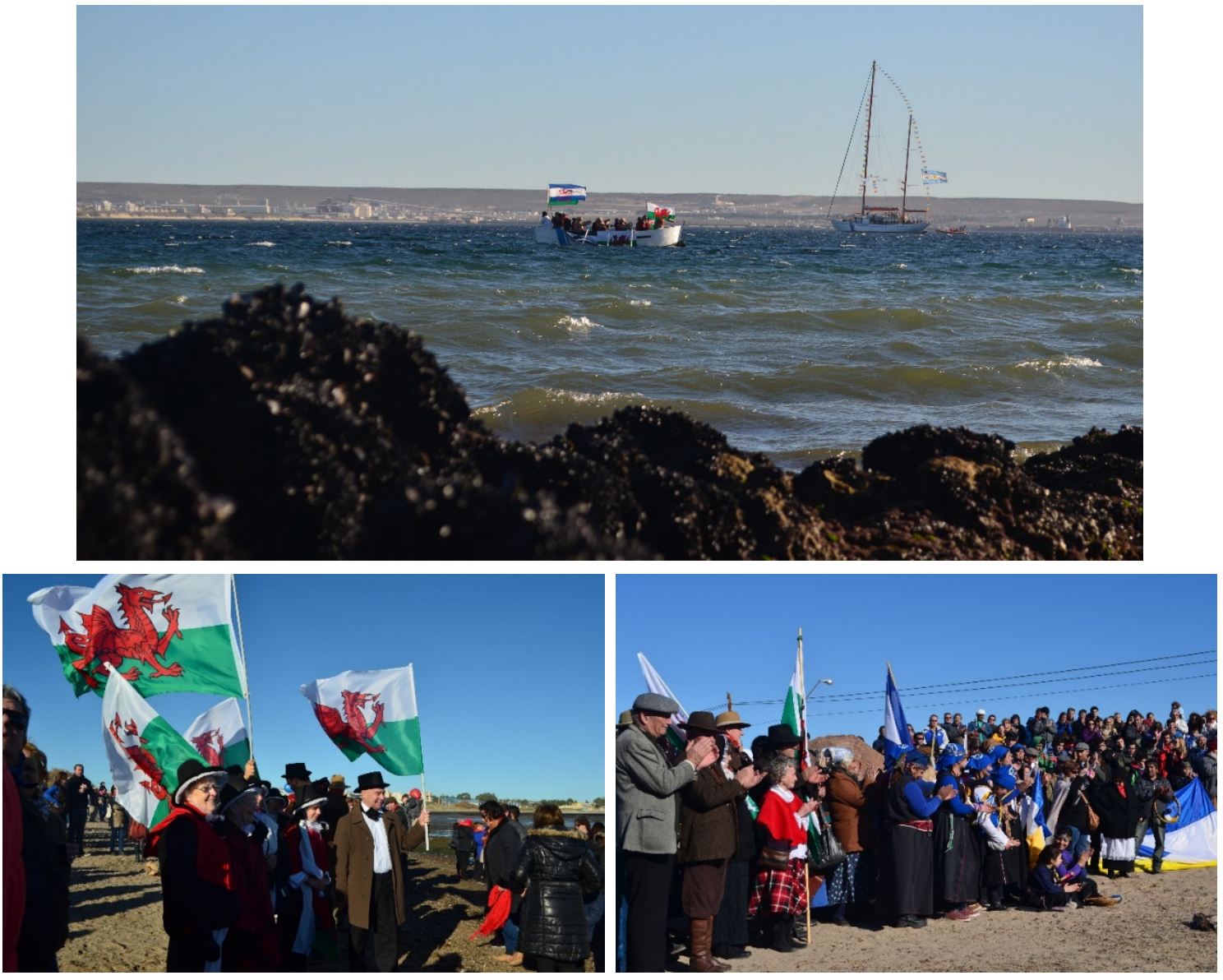

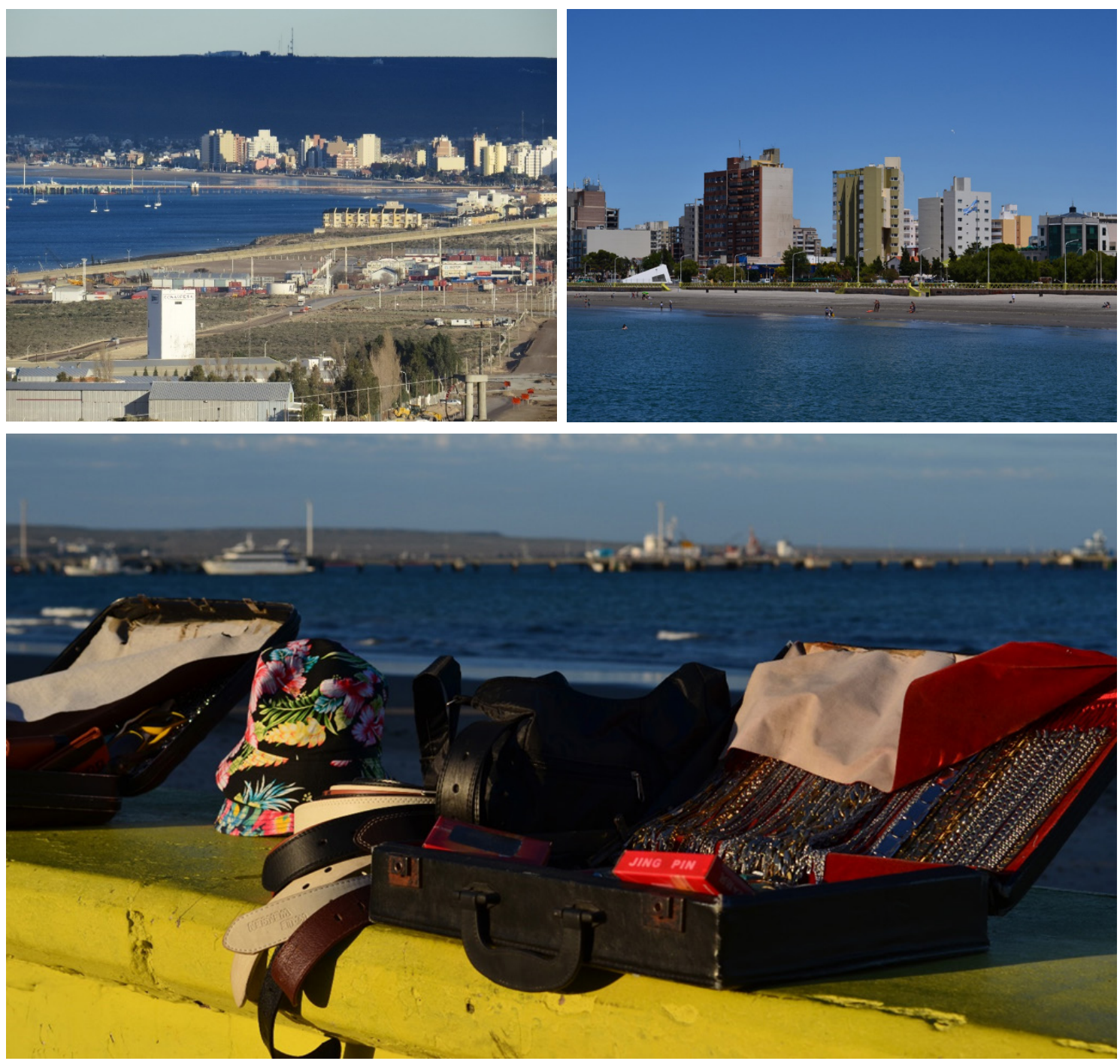

Mosaico 1: Disputas por el modelo dominante de ciudad en Puerto Madryn

Fotos 1, 2 y 3: Celebración del 28 de julio por el " $150^{\circ}$ Aniversario de Puerto Madryn" (como se nombró oficialmente la celebración) o "Sesquicentenario de los Galeses en Chubut" (como se nombró la celebración desde el

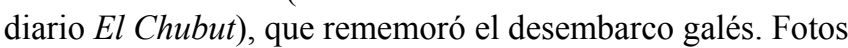
de Luz Espiro, 2015. Foto 4: Industrias, costa y desarrollo.

Foto de Carolina Laztra, 2013. Fotos 5 y 6: Comercio senegalés en la rambla. Fotos de Luz Espiro, 2016

en escena para hacer funcionar una división y jerarquización compleja de la ciudad". 
A continuación me adentro en el caso específico de la migración senegalesa y su inserción en el devenir de la ciudad de Puerto Madryn presentado hasta aquí. Cabe destacar que este colectivo migratorio no figura en los censos poblacionales (así como tampoco ha sido estudiado previamente en este contexto patagónico).

\section{Dinámicas comerciales estacionales de migrantes de origen senegalés en Puerto Madryn}

En base a las indagaciones realizadas en la delegación local de la Dirección Nacional de Migraciones (DNM), fue durante el verano de 2008 cuando se registraron las primeras solicitudes de refugio a migrantes de origen senegalés ${ }^{10}$. Se trata de unos pocos casos que constituyen el primer registro formal del que se cuenta sobre la presencia de dichos migrantes en la ciudad de Puerto Madryn, y las fechas coinciden con las declaraciones de mis interlocutores senegaleses y senegalesas sobre el momento en que llegan los primeros a trabajar aquí. Hacia el año 2011 ya se registra un aumento en los trámites en esta delegación, vinculados todos a peticiones de refugio ${ }^{11}$. Sin embargo, no se trata de personas que residan prolongadamente en Puerto Madryn, sino de una permanencia estacional estival, que se extiende desde diciembre hasta fines de marzo, o hasta el feriado de Semana Santa, llegando por grupos en diferentes momentos de este período.

Sin embargo, en el año 2016 en esa misma delegación de la DNM se registra la solicitud de refugio de un migrante senegalés que acude por primera vez a esta oficina, y quien se instala a vivir en la ciudad con motivo de una relación de pareja con una mujer local. Hacia 2018 se instala el segundo migrante del mismo origen. Si bien al inicio de su trayectoria en la ciudad ambos se dedicaban al comercio callejero, hoy sólo el segundo continúa con esta actividad laboral, porque al momento de escribir estas líneas el primero se encontraba en búsqueda de otro empleo. Estos son los únicos dos migrantes senegaleses que en el lapso de mi estudio eligieron Puerto Madryn para

\footnotetext{
${ }^{10}$ Entre Argentina y Senegal actualmente no hay representación diplomática directa, entonces entre las estrategias adoptadas por estos migrantes para regularizar su estatus jurídico, la solicitud de refugio es la principal opción con la que cuentan. Por ello casi todo senegalés y senegalesa que llega a Argentina inicia el trámite de solicitud de refugio ante la Comisión Nacional para los Refugiados (dependiente de la DNM), como alternativa para obtener la residencia precaria, documentación legal del país, siendo muy pocos los que han obtenido el estatus de refugiado. Este es el caso de los primeros migrantes que llegaron a Argentina en la década de 1990, originarios de Casamance, zona sur de Senegal donde se desarrolló un conflicto armado entre 1982 y 2014 por los intentos de secesión de dicha región del resto del país.

${ }^{11}$ Desde ese momento prácticamente la totalidad de los africanos que realizaron algún trámite aquí son senegaleses, exceptuando un varón de Costa de Marfil.
} 
residir de manera prolongada. Luego al año siguiente un tercero se instaló en la ciudad, lo que en palabras de un funcionario de la DNM local:

Este puede ser el inicio de una colectividad de senegaleses en Madryn (2019, en comunicación personal).

Sin embargo, cabe mencionar la presencia de migrantes senegaleses que viven de manera permanente en otras ciudades cercanas a la costa atlántica en la provincia de Chubut, como Trelew (la ciudad más próxima ubicada $60 \mathrm{~km}$. al sur) donde también hay tres varones senegaleses casados con mujeres locales, mientras que en Comodoro Rivadavia (445km. al sur de Puerto Madryn) su presencia estable oscila entre unas once y quince personas. En todos los casos, también se dedican al comercio, pero con una inserción marginal en el circuito de venta en las playas del norte chubutense.

Como dijera Baba, uno de los senegaleses residentes en Trelew:

Yo soy el primer negro que entró acá. Hace trece años que vivo acá, tengo esposa acá y dos hijos (...) es un buen lugar para vender, mejor que Buenos Aires, allá hay muchos, mucha competencia (...) acá la gente cobra y le sobra (Baba, Trelew, 2017).

Al consultarle sobre la posibilidad de venta en Puerto Madryn en el verano respondió:

Una vez fui, pero no tengo más ganas de moverme, trabajo acá todo el año (Baba, Trelew, 2017).

En base a estimaciones propias, eran cincuenta las personas de origen senegalés que llegaron la última temporada estival de mi estudio a Puerto Madryn para trabajar en la venta ambulante. Es casi en su totalidad una población masculina, sólo conocí a dos mujeres en la primera estadía de trabajo de campo, y una tercera en la segunda ${ }^{12}$.

Es durante el verano cuando estos migrantes delinean un circuito de movilidad interregional con extensión transnacional, motorizado por las prácticas laborales y asentado en redes de los y las migrantes. Sucede que durante las vacaciones de verano, en las grandes ciudades donde estos migrantes residen de manera más prolongada, las

\footnotetext{
${ }^{12}$ Cabe mencionar que en la DNM local se registra el paso previo de otra mujer en 2010. Esto coincide con el perfil altamente masculinizado de este grupo migratorio, a nivel nacional. La Asociación de Residentes Senegaleses en Argentina estima entre 4000 y 5000 migrantes de este origen en todo el país, de los cuales sólo 50 son mujeres, el resto son varones. Esto responde a las estrategias familiares en origen basadas en una persistente división hegemónica del trabajo, según la cual los hijos varones son los candidatos a la emigración para el envío de remesas mientras las mujeres tienen funciones reproductoras y la migración sigue resultando una actividad "mal vista" para ellas, aunque poco a poco se han ido incorporando a la movilidad internacional. Se trata de personas entre los 20 y los 47 años de edad, cuya ocupación principal es el comercio callejero de bijouterie de fantasía y productos de marroquinería. También cabe destacar su pertenencia a la religión musulmana (principalmente a las cofradías Muridiyya y Tijaniyya) y una identificación étnica wolof mayoritaria.
} 
ventas merman considerablemente. Como comentaba un migrante senegalés residente en la C.A.B.A que vendía en la costa atlántica bonaerense:

Cuando viene el verano la gente toma vacaciones, mucha gente se va de Buenos Aires, no tenés nada para ir vendiendo y allá no podes tener nada para vivir, entonces nosotros nos escapamos para acá (Reiter, 2010: 8).

En este momento la ciudad de Puerto Madryn se convierte en un punto turístico principal de la Patagonia costera marítima y la venta en la playa una estrategia adoptada por migrantes senegaleses y senegalesas para mejorar las oportunidades de su negocio. Ya que la ciudad alberga a turistas de diferentes puntos del país, recibe menos comerciantes senegaleses que otras ciudades costeras, y presenta otras condiciones de mayor tranquilidad para ejercer su trabajo, como la "flexibilidad" de los controles municipales de inspección, que no presentan la violencia institucional observada en otras ciudades argentinas.

En esta coyuntura urbana, senegaleses y senegalesas encuentran la posibilidad de acumular recursos económicos para gestionar la continuidad de su proyecto migratoriolaboral, mediante la intensificación del trabajo concentrado y la estructuración de redes con vínculos más o menos fuertes que se articulan para este momento ${ }^{13}$.

Las y los migrantes senegaleses que llegan cada verano a Puerto Madryn, provienen de la Región Metropolitana de Buenos Aires (Ciudad Autónoma de Buenos Aires, Gran Buenos Aires y La Plata) y de otras regiones argentinas como Cuyo, también de la provincia de Córdoba y otras provincias patagónicas, cuando finalizan fiestas y ferias locales donde también trabajan vendiendo. Asimismo constaté el arribo desde Brasil y unos pocos desde Senegal o Europa ${ }^{14}$. La información de que esta ciudad es un lugar conveniente para trabajar circula en la forma de recomendaciones al interior de las redes en las que participan estos migrantes, redes de amistad, de paisanazgo, de parentesco, pero también redes laborales y religiosas ${ }^{15}$.

Como se introdujo arriba, entre las particularidades que estos migrantes destacan de la ciudad como un lugar conveniente para trabajar, comentan que si bien la temporada de vacaciones tiene aquí una duración más corta en relación a otros lugares

\footnotetext{
${ }^{13}$ Además de juntar dinero para reinvertir en su actividad comercial, la expectativa también es lograr un envío importante de remesas a Senegal, una vez finalizada la temporada. En la ciudad existen dos empresas para enviar dinero: Western Union y Argenper. La primera -con un costo más alto del servicioes la que los senegaleses acostumbran usar por su presencia en varias ciudades y en su país de origen.

${ }^{14}$ Para ampliar este tema con relatos de los propios migrantes ver (Espiro, 2016, 2017).

${ }^{15}$ Cabe reparar que en esta ciudad identifiqué una cadena migratoria de Khombole (región de Thiès, Senegal) de donde son originarios un grupo de varones vinculados por parentesco y/o amistad desde ese lugar de origen, quienes arriban a Puerto Madryn en distintas etapas desde sus lugares de residencia, ya sea en Argentina o sur de Brasil.
} 
de veraneo, hay menor presencia de "chicos" o "africanos" -como ellos se refieren a sus "paisanos" comerciantes, otra denominación emic- es decir, menor competencia, coincidiendo con la versión de Baba sobre Trelew. Lo cual me permite inferir una tendencia en la elección de ciudades patagónicas por parte de migrantes de origen senegalés, por la lejanía de las principales metrópolis donde la presencia de compatriotas que trabajan en la misma actividad es mayor. Asimismo, existe cierto imaginario de que en Puerto Madryn los controles municipales son más laxos y por ende las posibilidades de venta más seguras. Sigue vigente la afirmación de Goldberg (2003: 137) en relación a que los comerciantes senegaleses:

[...] Escogen, rutas y lugares de más venta en función de, al menos, dos factores: 1) la relación entre la oferta de productos que posean en cada momento y la demanda de la clientela; y 2) las condiciones de seguridad para desarrollar la venta (principalmente, presencia de policía y accionar de esta: si sólo echa, si además multa y confisca o si detiene y se corre el riesgo de expulsión).

Pero también, al contar con oficinas de la DNM emplazadas muy cerca de sus lugares de venta -de hecho algunos comerciantes quedan ubicados enfrente- Puerto Madryn ofrece la oportunidad de gestionar trámites y renovar su documentación. Un elemento importante en las lógicas de movilidad de estos migrantes y que podría significar un recurso adicional para elegir esta ciudad. Al tratarse de una oficina pequeña y de trato casi personalizado, permite que sea más fácil realizar estos trámites en comparación con las grandes metrópolis, como también fue constatado en ciudades intermedias brasileras, como en Caxias do Sul (Herédia, 2016, en comunicación personal).

Finalmente, otro aspecto central en estas dinámicas y directamente vinculado a los modelos de ciudad que condicionan las sociabilidades en Puerto Madryn, se refiere al lugar donde migrantes senegaleses y senegalesas llevan adelante sus actividades comerciales. Estas se concentran exclusivamente en la franja costera de la ciudad, el llamado "sector paseo costanero", donde distinguí dos espacios de venta combinados: la zona de la rambla y la zona de la playa propiamente dicha. Si bien ambas coinciden en su trayecto - la rambla está emplazada adaptándose al perfil de la línea de la playa- los lugares que los migrantes ocupan y recorren en ambos espacios varían. A lo largo de la jornada un comerciante puede empezar exhibiendo su mercadería de manera fija en la rambla y a una determinada hora bajar a la playa para exhibirla caminando, o viceversa. 
Desde el muelle Comandante Piedrabuena ${ }^{16}$ al norte, hasta la altura del hotel Rayentray -que asoma como una masa enorme de hormigón en la línea baja de la costa y actúa como límite sur en el recorrido de estos migrantes- la distribución de los sectores de venta de senegaleses y senegalesas en la rambla depende del orden de llegada, es decir de los lugares libres que van quedando. Pero en el caso de la playa, cada quien sigue el itinerario que quiere. Por ejemplo, Billy, uno de mis interlocutores principales, llegaba a su puesto costero alrededor de las 11 o $12 \mathrm{hs}$ y permanecía hasta las $21 \mathrm{hs}$, ubicándose entre los últimos de sus paisanos en las escalinatas contiguas a uno de los paradores de la playa, donde ofrecía sus productos extendidos sobre el muro de la rambla.

${ }^{16}$ El más chico de los dos que hay en la costa, y de ingreso libre. En la zona industrial hay un muelle de mayor longitud, el Almirante Storni, para uso de ALUAR y de buques portacontenedores. 

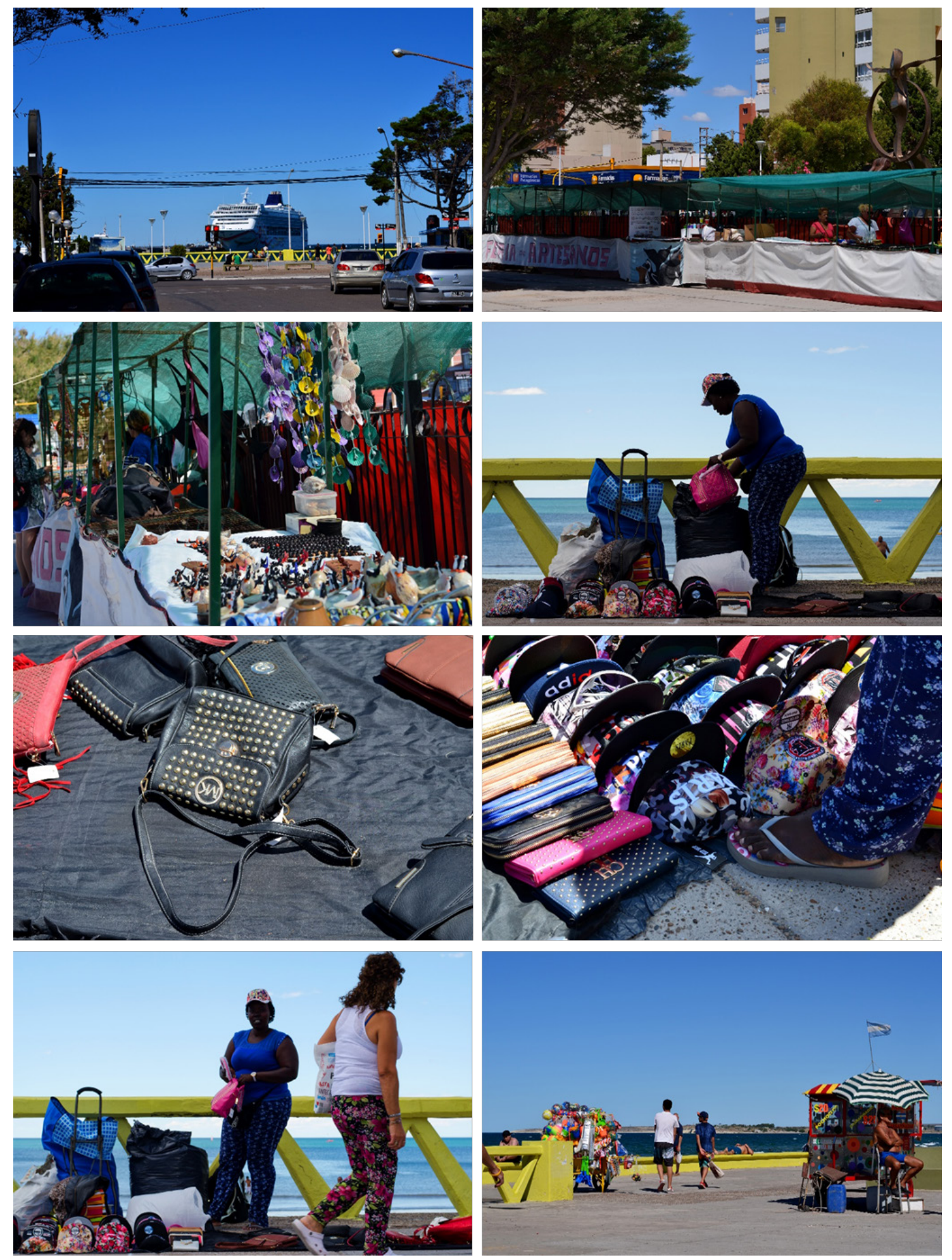

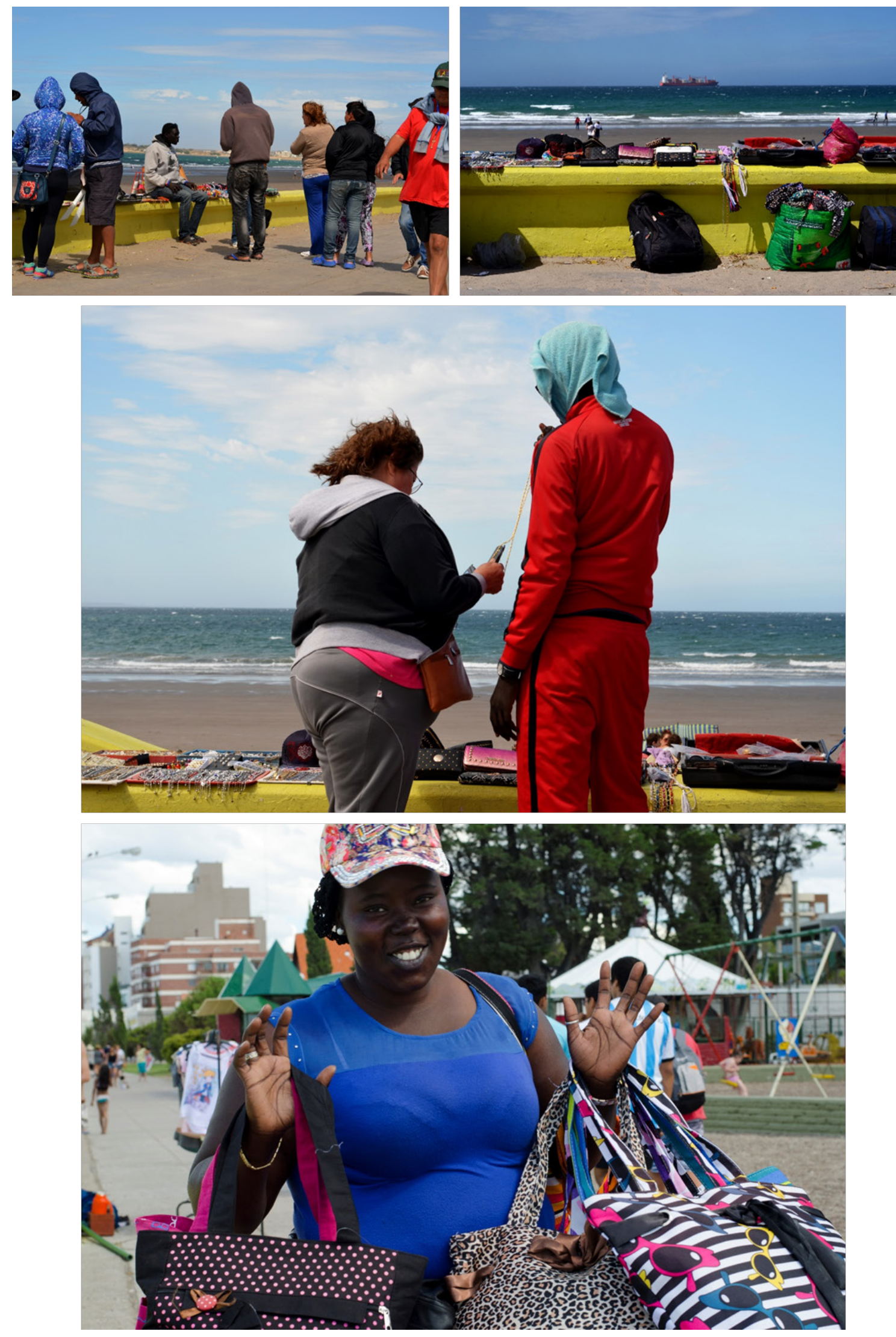

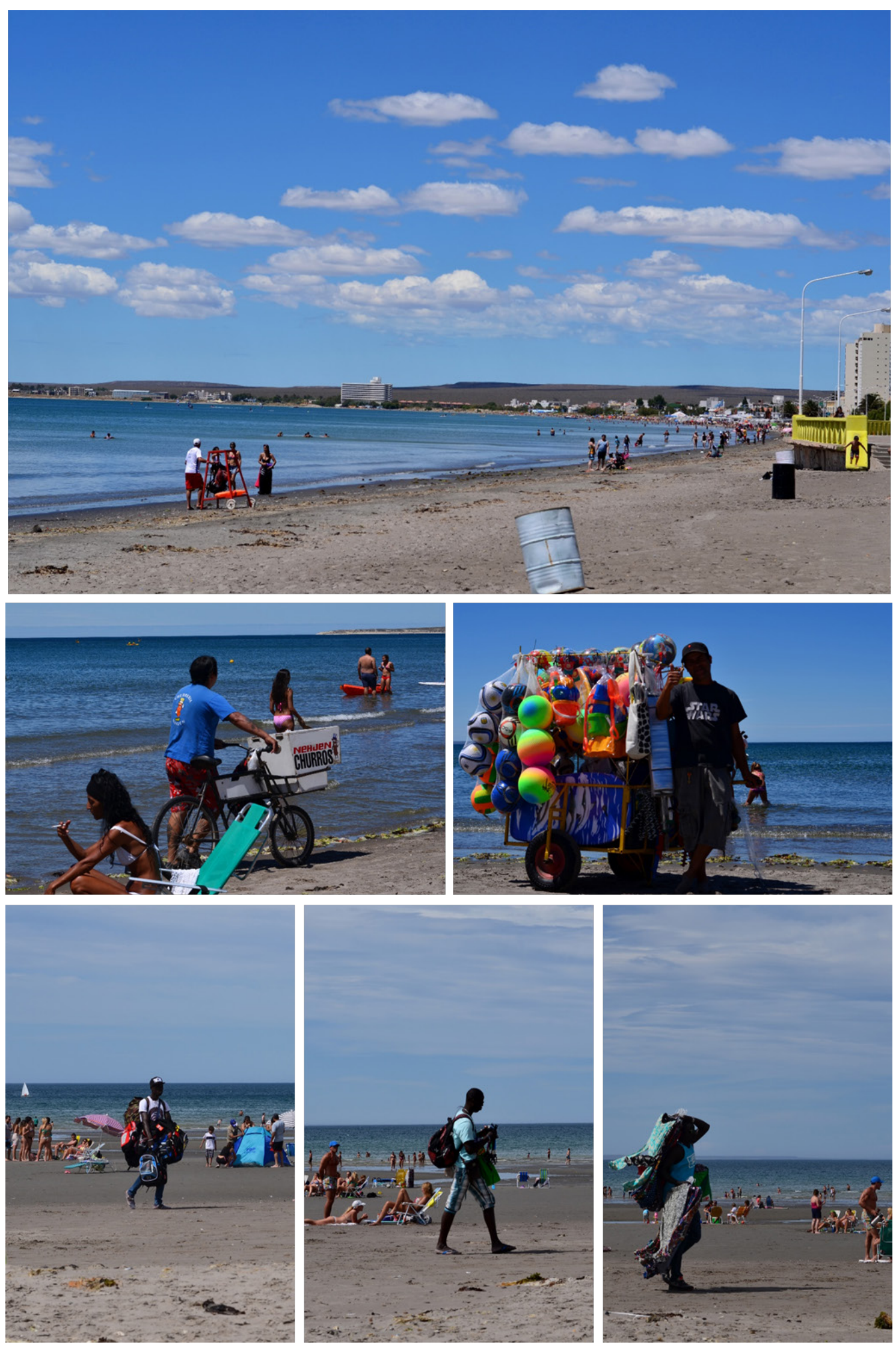

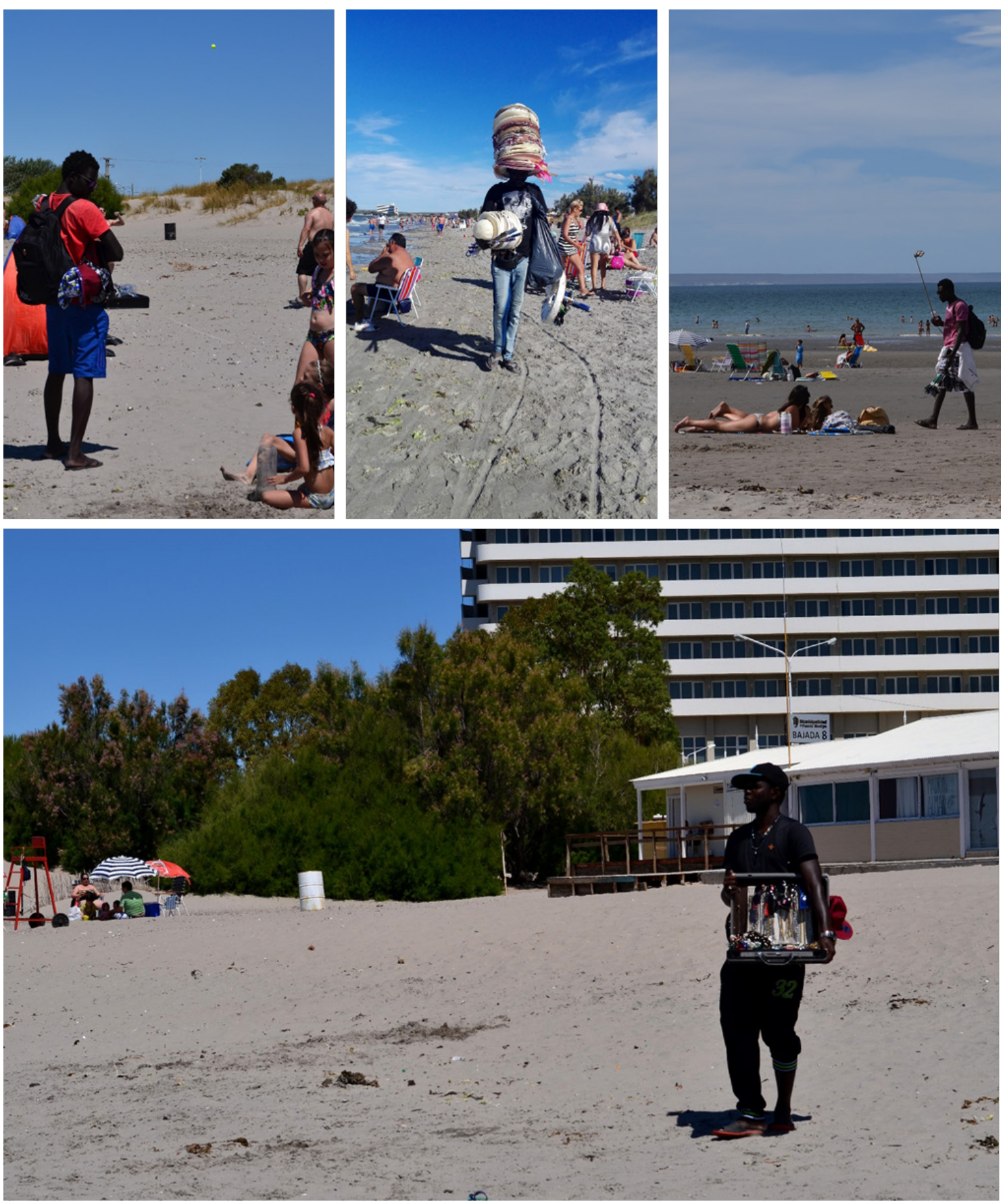

Mosaico 2: Vendedores ambulantes en el sector "paseo costanero" de Puerto Madryn. Las dinámicas del comercio senegalés combinan la venta en la rambla, de manera fija, con la venta en la playa, de modo ambulante.

Fotos 1 a 22: Luz Espiro, 2016 y 2017 


\section{Narrativas de la sociedad receptora sobre comerciantes de origen senegalés}

Como mencioné en la introducción, una ciudad no es sólo la materialidad de su infraestructura, sino también la totalidad de narrativas e imaginarios que elaboran sus habitantes sobre ella y las personas que la ocupan. Cabe recordar que, si por un lado, estos relatos inciden en los modos en que se transforma la ciudad, también las características urbanas moldean los procesos sociales, condicionando los vínculos interpersonales. "La disposición territorial condiciona — como posibilidad y como límite_ las relaciones y las estrategias de supervivencia" (Perelman, 2017: 12).

La presencia de migrantes de origen senegalés vendiendo en las playas madrynenses vino a poner en entredicho, fundamentalmente, el modelo de servicios y turismo dominante en la ciudad de Puerto Madryn en el verano, lo que desencadenó un vínculo conflictivo entre las partes. Adhiero a Perelman (2017) cuando plantea que los espacios urbanos heterogéneos percibidos como "anomalías" en su trama son el "efecto de la creencia de que el suelo refleja linealmente la estructura social" (Ibíd.: 12), creencia que se sustenta en esos relatos dominantes de sociedad y de ciudad presentados más arriba, según los cuales "la jerarquía espacial se corresponde con las sociales y económicas" (Ibíd.).

Como expresara Aníbal, un habitante local:

El NyC al considerarse algo exótico, ¿no?, tenés "hay el senegalés, el negro que viene, ¡huy qué bueno!”, pero en general el $\mathrm{NyC}$ siempre es reticente a todo (...), no le gusta que venga nadie, y además tiene como una escala de niveles de personas, primero el nacido y criado y después viene el resto, que "no conocen bien la ciudad" ese resto, "ni forman parte real de la ciudad" ese resto. Entonces el NyC lo rechaza como a todo, pero al ser algo exótico tiene cierto grado de simpatía entre comillas (Aníbal, Puerto Madryn, 2015).

De esta manera, se hace evidente que aquello percibido como "anomalías sociourbanas" por parte de las élites dominantes varía en el tiempo y para corregirlas estos sectores se valen tanto de las normativas (también cambiantes), como de las representaciones de los medios de comunicación, de la gestión penal y la fuerza policial. Por ello, "para entender las relaciones urbanas, hay que comprender las burocracias que las rigen y los medios de comunicación que las representan (Ibíd.: 13)”.

Siguiendo estos postulados, profundizaré a continuación en las interacciones que estos migrantes mantuvieron con dos actores locales, cuyas prácticas y discursos juegan 
un rol central en la defensa de los modelos dominantes de ciudad, al erigirse como sus guardianes: los agentes estatales de control y los medios de comunicación. En relación a los primeros, consideré el estado en su nivel municipal, específicamente el rol de la Dirección de Inspección General y Control Alimentario municipal (de ahora en más Inspección General). Hay que tener en cuenta que estos agentes "se constituyen en interlocutores cotidianos de estos extranjeros a partir de la co-presencia en la vía pública y por el control y regulación del espacio público y su uso" (Morales, 2010: 123). En relación a los segundos, Stuart Hall (2010) plantea que los medios de comunicación son un dispositivo protagonista en la construcción de sentidos en el mundo contemporáneo, en el que los migrantes específicamente (aunque no exclusivamente) son representados en torno a una cantidad acotada de temas estereotipados y con valoración negativa (ilegalidad, delitos, problemas de integración, drogas), lo cual "enfatiza su diferencia, desviación y amenaza" sostiene Teun Van Dijk (2006: 23). Teniendo en cuenta estas consideraciones, del espectro de la prensa gráfica local más leída consideré el periódico El Chubut.

\section{Relaciones urbanas 1: comerciantes de origen senegalés y agentes estatales de control}

En la ciudad de Puerto Madryn para ejercer la venta ambulante hay que contar con un carnet municipal que otorga Inspección General ${ }^{17}$, dependiente de la Subsecretaría de Gobierno de Puerto Madryn ${ }^{18}$. Es la Ordenanza n ${ }^{\circ} 9237$ la que actualmente rige la venta ambulante y dispone los controles para que se lleve a cabo dentro de su normativa ${ }^{19}$. El trámite de autorización del carnet exige presentar una identificación personal (Documento Nacional de Identidad, residencia precaria o pasaporte en el caso de personas migrantes), una foto carnet y abonar un monto mensual de diciembre a marzo. Dicho monto únicamente para las y los senegaleses es diferente del resto de los vendedores ambulantes y varía de temporada a temporada (por ejemplo, para enero de 2016 era de \$800, mientras que para 2017 costaba $\$ 1200$ para dichos comerciantes migrantes). Si bien un requisito estipulado por esta ordenanza es acreditar

\footnotetext{
${ }^{17}$ Se tramitan personalmente en sus oficinas, alejadas del radio céntrico, de la franja costera y de la zona de viviendas alquiladas migrantes senegaleses.

${ }^{18}$ El intendente Ricardo Sastre, del espacio político "Chubut Somos Todos", se mantiene en el gobierno de la ciudad desde 2011, pero el mando de Inspección General cambió hacia 2015. Es con la anterior Directora, Adriana Vílchez, con quien se dieron situaciones iniciales de tensión, enfrentamiento y negociación con los senegaleses en relación a la venta ambulante, que adquirieron dimensión mediática y que cambiarían el modo de representación sobre estos migrantes.

${ }^{19}$ Surge por modificación de la Ordenanza n ${ }^{\circ} 5294$ vigente hasta diciembre de 2015.
} 
más de cinco años de residencia en Puerto Madryn, estos migrantes están eximidos de cumplirlo, pero, en contrapartida, cada verano se establece discrecionalmente un cupo exclusivo $-\mathrm{o}$ excluyente- para ellos/as (alrededor de 15 carnets), muy inferior a la cantidad efectiva que llega.

Los senegaleses vienen en temporada, hacen plata y se van, mientras que los demás viven acá todo el año. [...]. En realidad a ellos no habría que darles permiso, esa es la realidad. Porque vos tenés que tener por lo menos cinco años de residencia acá en Madryn, para poder tener el permiso de venta ambulante. Pero por una cuestión de que la gente pide que estén los senegaleses (Vanina, funcionaria de Inspección General, Puerto Madryn, 2016).

Acá les pedimos cinco años de residencia en la ciudad para obtener su permiso, porque si no viene gente a ganar en la temporada y después se va y acá quedan los demás. Pero ahora tenemos el tema de los senegaleses, que están en todos lados y que se los damos, aunque ellos no se instalan a vivir, por ahora... (Lidia, funcionaria de Inspección General, Puerto Madryn, 2016).

Además de las desigualdades en las condiciones laborales que esto suscita, muchos senegaleses en Puerto Madryn se ven excluidos de la posibilidad de adquirir el carnet y forzados a ejercer irregularmente su práctica laboral. En última instancia, la implementación no reglamentada de cupos para ellos/as es un mecanismo indirecto de control y restricción para su llegada a la ciudad, como parte de la gestión que el municipio de Puerto Madryn lleva adelante para contener "el problema de la inmigración". Me refiero al temor a una diversidad indeseada o supuestamente inmanejable, sobre todo, en sociedades con concepciones identitarias exclusivistas (Arango, 2003). Entonces, frente a la realidad contraria -de continua llegada de migrantes de origen senegalés durante el verano, aunque en bajas cantidades comparado a otros centros turísticos- acaba generando condiciones laborales de inseguridad y vulnerabilidad para estos migrantes.

Estas dinámicas que intersectan lo migratorio y lo estatal, se despliegan en el “campo de la contravencionalidad" (Perelman, 2017: 19):

Un campo de burocracias particulares que activan y sostienen procesos judiciales y de monitoreo social. Lo contravencional asume el carácter de un subsistema legal, judicial y de gobierno. Un subsistema que puede ser ignorado para los sectores que viven la ciudad según los usos dominantes pero que revela su carácter regulatorio y punitivo para quienes habitan y trabajan en la ciudad a contramano y a contraturno.

En trabajos anteriores profundicé en un episodio resonante que involucró a estos migrantes, ocurrido durante enero de $2014^{20}$, un mes de gran tensión social en la ciudad de Puerto Madryn, por sostenidas huelgas de los trabajadores de ALUAR y Alpesca S.A. (empresa pesquera). A inicios del mes, Inspección General no les permitió tramitar

\footnotetext{
${ }^{20}$ Ver Espiro (2019) y Espiro, Voscoboinik y Zubrzycki (2016).
} 
el permiso de venta ambulante a migrantes de origen senegalés, esgrimiendo que la normativa local no autoriza la comercialización de productos de reventa en la zona costera $^{21}$, específicamente sus artículos, que no calificarían como "artesanales" -cabe destacar que por disposición municipal los vendedores ambulantes no pueden participar en ninguna de las ferias que hay en la ciudad, reservadas para los artesanos. Entonces, en contrapartida les proponían vender en el barrio San Miguel, un barrio popular de la periferia de la ciudad, alejado de la playa y del centro ${ }^{22}$, donde se concentran los potenciales clientes. A todas luces, se trataba de una opción incongruente con las expectativas del proyecto laboral estacional que representa Puerto Madryn para estos migrantes, pero acorde a las expectativas del modelo de servicios y turístico de ciudad que se busca proteger.

Dicha propuesta fue rechazada por los comerciantes senegaleses, quienes realizaron una serie de denuncias en el Instituto Nacional contra la Discriminación, la Xenofobia y el Racismo (INADI) y en diversos medios de comunicación locales, esgrimiendo que se trataba de un hecho de racismo y discriminación. Con estas estrategias se dilató la resolución del proceso hasta el final de la temporada, mientras que las y los migrantes senegaleses sostuvieron su venta en las playas de Puerto Madryn, sin desaprovechar el esfuerzo que conlleva llegar hasta allí y sin renunciar a las posibilidades de engrosar sus

ganancias. Pero lo hicieron sin el respectivo carnet y en una situación de mayor vulnerabilidad, frente al peligro que suponían los controles municipales de inspección, que se dieron de manera sostenida durante esa temporada y los tenían como objetivo principal.

Durante los veranos anteriores y subsiguientes a este episodio, tanto aquellos migrantes que no pudieron tramitar el carnet de venta como quienes sí lo obtuvieron también están quienes eligen no tramitarlo, corriendo mayores riesgos-, deben estar atentos por igual a la amenaza que supone la llegada de los inspectores. Suelen ser unos treinta y cinco distribuidos en dos turnos, mañana y tarde, y es por lo general en el turno

\footnotetext{
${ }^{21}$ La ordenanza distingue tres zonas de venta ambulante (A, B y C). La zona B es la codiciada y que genera conflictos, porque "comprende el sector paseo costanero, entendiéndose como tal, al espacio entre la primera arteria paralela a la playa y el mar". La oferta que el municipio les hacía ese verano consistía en tramitar el carnet de venta ambulante para la zona C que "comprende el resto del ejido Municipal" por fuera de la costa y de la zona céntrica (incluida en la A).

${ }^{22}$ Nótese, que el barrio San Miguel directamente queda por fuera del mapa turístico oficial de Puerto Madryn, que tampoco es a escala, por lo cual la distancia entre el sector "paseo costanero" y dicho barrio es bastante mayor de lo que se aprecia (Pág. 23).
} 
de la tarde que realizan inspecciones a vendedores ambulantes, coincidiendo con su mayor presencia y trabajo. La mayoría de las veces, los controles "de rutina" los realizan solamente los inspectores municipales. En algunos casos, se realizan procedimientos conjuntos con la DNM y la Administración Federal de Ingresos Público (AFIP) para verificar su situación migratoria y la procedencia de los productos de venta. En otros casos participa también la policía provincial. Estas dos últimas modalidades de inspección son calificadas como "operativos” desde la misma Dirección.

Los objetivos de los controles de rutina incluyen que los y las comerciantes de origen senegalés tengan el carnet correspondiente, que no armen puestos grandes (obligándolos/as a vender separados entre sí), que la mercadería exhibida coincida con la acreditada en el carnet y que no vendan anteojos de sol ni relojes. Cuando los inspectores detectan su comercialización proceden al secuestro de esta mercadería. Desde Inspección General sostienen que:

\begin{abstract}
El problema que hay con los senegaleses es que ellos traen mercadería que no pasa por Aduana, que de última tampoco es un problema de ellos, ellos la consiguen, a ellos se la dan. Entonces si vamos al caso, como me decía Liliana [Directora de Inspección General] una vez, 'hay un problema en Aduana', alguien está dejando pasar. Nosotros lo que hacemos acá es notificarle que no pueden vender relojes, porque es un delito en el sentido de que no pasa por Aduana. Y el tema de los anteojos está por ley, acá hay una ordenanza, o sea una ley que dice que no podés vender lentes, ni de sol, ni de contacto, ni de ningún tipo si no está certificado por un técnico, o sea por un oculista. (...) cada dos por tres, pum, sacamos un montón de anteojos (Vanina, funcionaria de Inspección General, Puerto Madryn, 2016).
\end{abstract}

Sucede que a la Ley de Marcas y Designaciones n²2.362/1980 que rige en todo el territorio nacional y penaliza la venta de productos falsificados o de imitación, se le agrega en Puerto Madryn la Ordenanza municipal n³25/92 (Despacho de anteojos) que insta a hacer cumplir la ley provincial por la cual la venta de anteojos de todo tipo es competencia exclusiva de ópticas habilitadas. Sin embargo, las y los migrantes senegaleses sostienen la comercialización de estos productos hasta el final de la temporada, porque son los que mayor porcentaje tienen en el total de sus ventas -por ende, de sus ingresos- y porque funcionan como un atractor para la compra de otros productos. Esto genera también el aumento de los controles, pero a pesar de que suelen ser regulares, dichos migrantes consideran que los inspectores mantienen un trato cordial con ellos, tal como comentara Narième, una comerciante senegalesa:

En otros lados ni te miran directamente, ellos saben que estamos laburando (Narième, Puerto Madryn, 2016).

Por su parte, la funcionaria de Inspección General sostenía que:

Nosotros estamos haciendo cumplir la ordenanza, no es que...a mí no me gusta venir y decirte "flaco, levantá las cosas y andate", porque es la realidad, uno sabe cómo 
está el país hoy y sabemos también que no hay laburo. No hay laburo entre comillas, si querés buscar. (...) nosotros ya teníamos un tipo de trato con ellos, no es que vos te hacés ni amigo ni nada, pero vos por ahí pasabas tenía tres relojes y para no entrar en..."guardá"...le decía, viste. Entonces ellos agarraban y guardaban para no entrar al choque. Ahora cuando se ponían pesados y entraban a "axwpnreix" (balbucea) y se ponían a hablar en su idioma... ahí y listo "dame los relojes, dámelos, no me voy de acá hasta que no me des" (Vanina, funcionaria de Inspección General, enero 2016).

La yuxtaposición entre las personas y la mercadería que venden las personas en cuestión, evidencia la cosificación de la que son objeto estos migrantes, cosificación que encierra una ambigüedad: funcional al modelo turístico de ciudad, por un lado; indeseada, por otro. La diversidad de productos en la playa que reclaman los turistas y habilitan las autoridades mismas del municipio se encarna en su marca fenotípica. Sin embargo, la misma marca racializada los hace objeto de inspecciones específicamente dirigidas, de cupos y costos a medida. Asimismo, la tolerancia que la demanda de exotismo pareciera regular, encuentra el límite cuando lo exótico se torna desconocido e inmanejable. Y aparece la desconfianza legitimando los procedimientos.

Mientras una inspectora me explicaba los diferentes tipos de carnet existentes, comentó:

Los morochos una risa, porque son todos iguales, les sacan foto y son todo iguales, te imaginás (risas) (...) su carnet se llena de la misma manera con la única diferencia es que el de los senegaleses sale como artesano o también como vendedor ambulante, porque como está fuera del...como para distinguirlo (risas), bueno, ellos ya por la piel los distinguís los permisos (Vanina, funcionaria de Inspección General, enero 2016).

En este comentario resuenan los planteos de Morales (2010: 133):

Ser negro y ser africano aparecen, en general, como sinónimos. Entre ellos no hay distinción, para estos agentes todos son 'africanos'. Por supuesto que hay un grado de veracidad en esta apreciación, la cuestión es cuáles son las consecuencias de esta generalización y homogenización en las relaciones interculturales cotidianas.

Estas representaciones estereotipadas de los agentes estatales de control le dan sentido y legitimidad a su accionar discrecional y abuso de poder. Siguiendo a Morales (Ibíd.) se trata de mecanismos de generalización, indiferenciación, homogeneización, sobredimensionamiento e incertidumbre, que focalizan sobre rasgos corporales como diacríticos, asociados con la hipervisibilización y la exotización, que operan en la base de las representaciones de los diversos sectores de agentes estatales de control e instauran los modos de relacionamiento para con los y las comerciantes de origen senegaleses. Asimismo, se pone de manifiesto que:

La policía [y en nuestro caso Inspección General] gobierna en los hechos una parte sustancial de la vida urbana y de las actividades que tienen lugar, especial pero no únicamente, en la calle y otros espacios públicos. (...) una parte de las ganancias que generan las actividades urbanas perseguidas es apropiada por la policía por 
mantener abierto un margen de tolerancia entre lo que las normas mandan y lo que diferentes grupos hacen. $\mathrm{O}$, al menos, entre la interpretación que la policía logra imponer de las normas y lo que deja hacer. El poder policial de dejar hacer lo que las normas prohíben o regulan se traduce concretamente en formas de explotación económica (...) sujetas a negociaciones y excepciones (Perelman, 2017: 16).

A inicios de diciembre de 2015 se introdujo una modificación en la ordenanza municipal vigente hasta la actualidad, que prohíbe la permanencia fija de los vendedores ambulantes en el espacio público durante el ejercicio de su trabajo y prescribe su circulación constante.

Lo único que se sacó de ese artículo digamos es que no diga que puede haber puesto fijo, ni de 12 horas, porque cada vez que un inspector va a controlar y está en un puesto fijo vos le decías 'no pero tenés venta ambulante', 'sí pero la ordenanza dice que yo puedo estar 12 horas si quiero acá', entonces se agarraban de eso... (Vanina, funcionaria de Inspección General, enero 2016).

Durante la temporada de verano de 2017 hubo cierta presión del municipio para que las y los comerciantes senegaleses cumplan con la nueva disposición y trabajen de manera estrictamente ambulante, modificando sus dinámicas habituales de combinar los espacios de venta de la rambla y la playa. Sumado a esto, el clima tampoco fue favorable, primó el viento usual de esta zona en esta época del año y los días nublados, lo que dejaba pocos bañistas en las playas y pocos paseantes en la rambla. Conversando con Narième comentó que:

Este año hubo mucho viento, hubo problemas con la municipalidad, nos pusimos firmes y les dijimos que los inspectores se quedaban con nuestra mercadería y la revendían, después de eso no volvieron a molestarnos, por ahora (Narième, Puerto Madryn, 2017). 


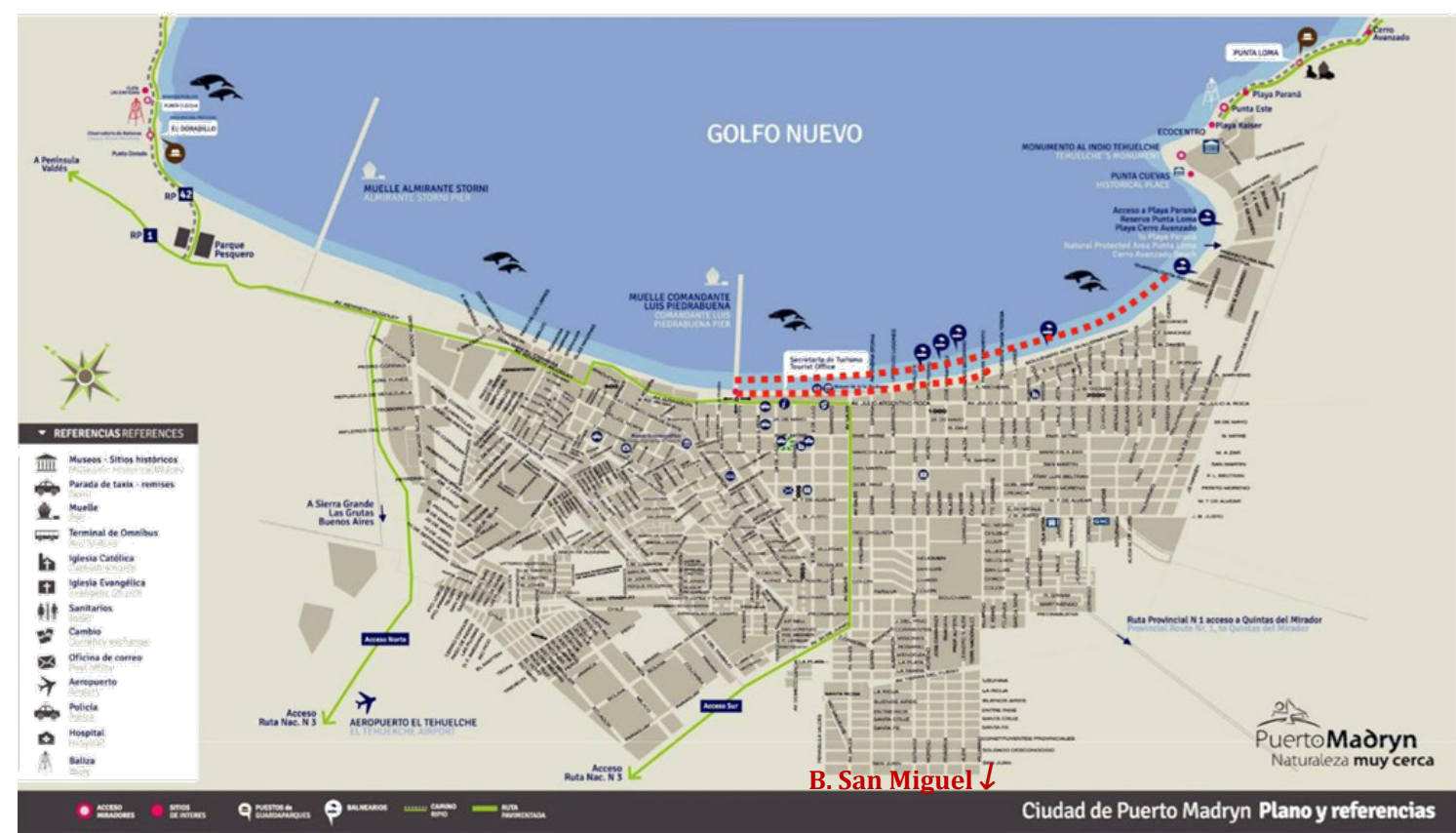

Distribución de los puntos de venta de comerciantes senegaleses en la rambla y en la playa de Puerto Madryn (punteado rojo).

Fuente: elaboración propia en base al mapa turístico oficial. 
APELLIDO:

NOMBRES:

DOCUMENTI DE IDENTIDAD:

SECTIR DE VENTA PERMITIDO:

VÁLIDA DESDE:

HASTA: AMBULANTE

PRIDUCTRS

\section{Rubros que se pueden explotar como vta ambulante}

\section{En cuanto a alimento}

+ Helados envasados

* Agua caliente para mate

* Productos de panificación (roscas- churros- pan casero - biscochos saborizados - tortas fritas) menos los productos de pastelería (nada que tenga cremas)

+ Gaseosas, agua mineral, jugos (todo envasado)

+ Ensaladas de frutas

+ Garrapiñadas

+ Pochochos

+ Manzanas azucaradas

$\downarrow$ Copos de nieve

+ Golosinas envasadas

\section{En cuanto a productos no alimenticios}

+ Pelotas

* Juegos de playa

* Indumentaria playera

+ Viseras (gorros, capelinas)

+ Bijouterie

+ Artesanías

Mosaico 3: Carnet y listado son instrumentos de control de la venta ambulante

1 a 3. Material escaneado de originales cedidos en Inspección General

El secretario de gobierno nos pidió que hubiera una diversidad, de... de...de cosas viste, porque siempre se ve o churros, churreros, o el vende pelota, o...

Entonces la explicación que siempre le damos es que en realidad nos regimos de la ordenanza de lo que se dice que se puede vender, para eso está la ordenanza.

(Vanina, funcionaria de Inspección General, enero 2016). 


\section{Relaciones urbanas 2: comerciantes de origen senegalés y medios de comunicación}

Cada temporada de verano se identifica en Puerto Madryn una dinámica particular en la que el control del espacio público a los fines de sostener y resguardar cierto modelo de ciudad, articula las acciones de los agentes estatales con las de los medios de comunicación (particularmente, prensa gráfica), dirigidas hacia los senegaleses y senegalesas que venden en la rambla, el espacio más codiciado para el modelo turístico de ciudad.

Llevé adelante entonces una revisión dirigida a identificar artículos periodísticos publicados por El Chubut ${ }^{23}$, entre 2012 a 2018, que tuvieran como referente a migrantes senegaleses ${ }^{24}$. De los 25 artículos recabados, un primer hallazgo permite distinguir "un antes" y "un después" de los episodios ocurridos en la temporada de 2014, cuando se les denegó la tramitación del permiso de venta exclusivamente a estos migrantes. Cabe recordar que estratégicamente ellos le dieron visibilidad al caso en los medios de comunicación locales, con uno de ellos -Billy- como su referente y vocero. De este modo, el diario El Chubut se convirtió en un "tribunal" durante unos días en los que las partes involucradas hacían públicos sus argumentos. A partir de entonces, cambiará el tipo de tratamiento dado a estos migrantes en dicho periódico y su consecuente construcción como un objeto discursivo delimitado y delimitable ${ }^{25}$ (Narvaja de Arnoux, 2009).

En los artículos publicados entre 2012 y 2013 los comerciantes senegaleses aparecen inicialmente como una novedad, la nota exótica que agrega un atractivo a la puesta en escena de la playa. Las descripciones de este escenario son un "inventario" de la variedad de situaciones, personas y elementos que allí parecieran coexistir sin conflictos, acorde al imaginario dominante de la identidad social madrynense que

\footnotetext{
${ }^{23}$ Se trata del periódico de mayor tirada de la ciudad, en un lugar donde la práctica de comprar el diario en papel aún persiste de manera amplia, incluso como actividad recreativa en la playa durante el verano. Allí circulan los canillitas, como se conoce a los vendedores callejeros de periódicos.

El Chubut fue creado en 1971 con una impronta popular en la ciudad de Trelew por un empresario de afiliación peronista. Si bien Kaminker señala que el hecho de contar con la redacción fuera de la ciudad de Puerto Madryn acarrea diferencias en "la centralidad de las noticias locales" (Kaminker, 2015: 327), el periódico publica de manera impresa un ejemplar enteramente dedicado a Puerto Madryn. El diario luego sería comprado y refundado en 1975 por otros empresarios, aliándose más o menos a todos los gobernadores provinciales -con excepción del ex gobernador Martín Buzzi (2011-2015)- valiéndole el mote de "boletín oficial".

${ }^{24}$ El trabajo de revisión fue iniciado en el archivo del diario, en sus oficinas centrales de la ciudad de Trelew en 2015, y prosiguió de manera online, a través de las publicaciones de su página web, hasta 2018.

${ }^{25}$ Se entiende por objeto discursivo a uno de los elementos -junto con las modalidades de enunciación, conceptos y elecciones temáticas- de las regularidades que se pueden reconocer en los discursos, entendidos como prácticas localizadas históricamente (Narvaja de Arnoux, 2009: 67).
} 
sustenta el modelo de ciudad turística. No obstante a fines de este período empiezan a aparecer otro tipo de representaciones.

Observé entonces que las inspecciones regulares -presentadas en el apartado anterior- eran complementadas con sanciones morales desde los medios de comunicación. Frente a lo que El Chubut instaló como una "competencia desleal", avivando el discurso estatal sobre la legitimidad/ilegitimidad del comercio ambulante, se apelaba a alzar la voz de comerciantes, principalmente de ópticas y relojerías locales:

Ellos vienen acá, se instalan dos meses y hacen mucha más plata que nosotros, muchísima, no pagan alquiler, ellos dan trabajo en negro y no hay cómo detectarlos (Comerciante, El Chubut, 7/1/2013)

Estropean la visual más linda que tiene la ciudad (Comerciante, El Chubut, $7 / 1 / 2013)$.

El año 2014 iniciaba en una coyuntura convulsionada en Puerto Madryn. Eran varios los sectores productivos que protagonizaban diversos tipos de reclamos y las tensiones entre el modelo industrial y turístico se agudizaba abiertamente, en un momento de la ciudad en que se pretende explotar al máximo el rédito económico de la temporada turística, con la llegada de veraneantes y de cruceros. Con los muelles y rutas de acceso a las ciudades interrumpidas, como parte de las estrategias de reclamos, el clima lejos estaba del regocijo, la tranquilidad y el disfrute que la ciudad turística pretendía ofrecer. Este diario publicaría una editorial titulada "Madryn: Hay que mantener la cordura para evitar el estallido", donde podía leerse:

La ciudad está pasando una coyuntura muy mala, que puede ser germen de protestas muy complicadas (...). Todo está en peligro y es hora de que los referentes se reúnan y apliquen soluciones racionales a los problemas, y que industriales, comerciantes, gremios y Estado actúen en equipo (...) Hay que volver al equilibrio de las cosas, a la naturalidad de una ciudad pujante y trabajadora. Los dirigentes, los empresarios, las cámaras que los agrupan, los gremios, los industriales, las iglesias, los científicos, las ONG que las hay, y muchas deben trabajar junto a la política y resolver los problemas (...) Madryn no soporta un conflicto más (El Chubut, 26/1/2014).

En este contexto, los senegaleses y senegalesas protagonizaron sus primeros enfrentamientos abiertos con el municipio, a los que les sucedían artículos de El Chubut que comenzaban a visibilizarlos como foco de conflicto y a su actividad comercial en clave ilícita. Inclusive en algunos casos su mención era tácita, aunque se hacía evidente que eran ellos los protagonistas de los hechos que el diario relataba. Impresionante operativo en la playa por vendedores nigerianos [sic] (El Chubut, 20/1/2014), Inspectores municipales controlan a vendedores ambulantes en la playa (El Chubut, 23/1/2014), Operativo de la AFIP en la playa contra vendedores ambulantes 
senegaleses (El Chubut, 24/1/2015), Secuestran mercadería apócrifa durante operativo de control en el sector costero (El Chubut, 20/1/2016).

A partir de entonces, la cuota de visibilidad de los y las migrantes de origen senegalés en el periódico de mayor tirada de la ciudad comenzó a vincularse, por lo general, con episodios problemáticos, produciendo una cadena de significantes del campo de la ilegalidad y el delito para una objetivación discursiva que reforzaba su representación criminalizante. Se observa que desde los medios de comunicación tradicionales que detentan la hegemonía discursiva, se expone y refuerza este clima social reticente a la inmigración y a los sujetos migrantes, contribuyendo muchas veces a reforzar una ideología racista (Morales, 2012). Como plantea Van Dijk "La gente de a pie, en general, imita y reproduce ese discurso dominante, a veces de una manera más extrema" (Morales, 2012: 2).

Al indagar sobre la mercadería comercializada por migrantes senegaleses, una empleada de una óptica céntrica comentaría:

Si no tenés plata para uno de estos [anteojos] mejor no uses nada. (...) Yo no digo que no vendan, que vendan anillos, bijouterie, pero que no se metan con la salud. (...) Ayer un cliente, un señor que no es óptico ni nada, publicó una denuncia en Facebook para que dejen de vender estos chicos, dominicanos, no sé qué son (Empleada de comercio, Puerto Madryn, 2016).

En su circulación, las producciones de los medios inscriben ininterrumpidamente la diferencia y la mismidad, proveyendo marcos que encuadran la producción de significados, representan lo que convencionalmente se reconoce como realidad y de este modo co-construyen la legitimación de situaciones socialmente asimétricas, porque orientan en esta dirección las regulaciones de las relaciones sociales (Rodríguez, 2011). En el paso de lo descriptivo a lo prescriptivo, ofrecen puntos referenciales de sentido tomados para clasificar y comprender a estos migrantes categorizados como una otredad radical, indeseada y problemática, alimentando este imaginario y reforzando, por tanto, la legitimidad del accionar de los agentes estatales de control y perpetuando la exclusión y el acceso desigual a diversos recursos por parte de estos sujetos. 


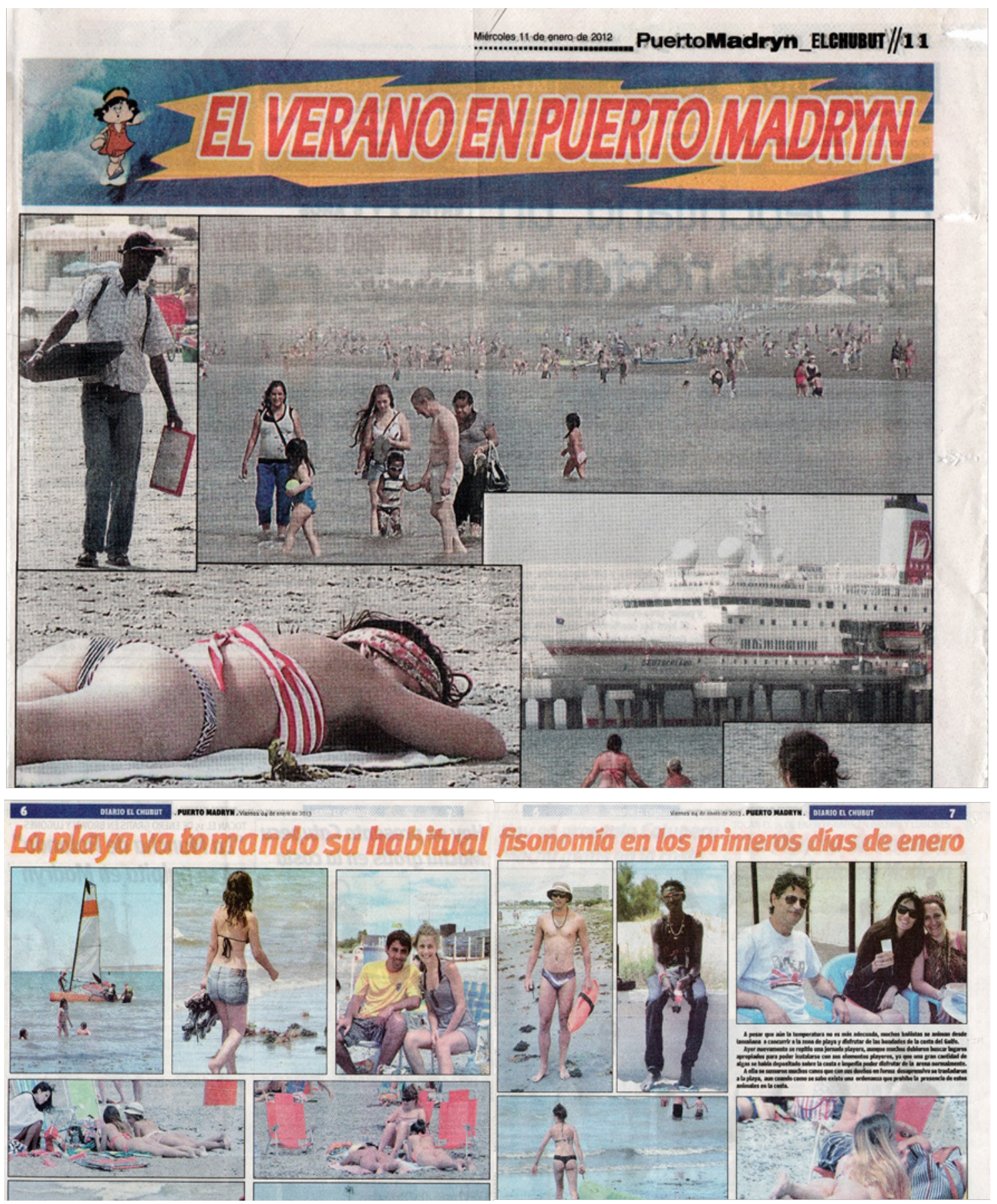

Mosaico 4: Los comerciantes senegaleses son representados como la oferta exótica del escenario costero prefigurado

1. (El Chubut, 11/1/2012) 2. (El Chubut, 4/1/2013) 
TRAS LA DENUNCIA EFECTUADA POR LOS SENEGALESES Mónica Saso: "Hay que reunir pruebas para luego tomar la denuncia"

\section{NO TIENEN PROBLEMA CON NADIE}

Durante la charla, Alium destacó que ellos no tienen "problemas con los habitantes, el único problema lo tenemos con una chica, Andriana Vílchez que no quiere que trabajemos. Nosotros tenemos toda la mercadería facturada, no tenemos problemas con la policía, la federal, con nadie, solamente con esta chica".

DIRECTORA DE INSPECCION GENERAL Y EL TEMA DE LOS SENEGALESES 4 Adriana Vílchez: "Esta es una acusación totalmente falsa"

Adriana Vilchez se pre- 5 sentó en la redacción de EL CHUBUT para ejercer su derecho a réplica y contar su versión de los hechos.

"Yo vengo a aclarar de que esa acusación es totalmente falsa, errónea; tengo de testigos a todo mi personal; las secretarias y estábamos todos; siempre se los trató de escuchar y darles una respuesta; básicamente 10 que hago yo es tratar de cumplir con la ordenanza y nada más; no avalo lo que esté fuera de término con esta situación", manifestó.

Mosaico 5: Enfrentamiento mediático entre comerciantes senegaleses e Inspección Municipal, con la intervención de INADI. 1 a 3. El Chubut, 22/01/2014 4 a 7. El Chubut, $25 / 01 / 2014$
NO LES DIERON LA HABILITACION POR SER NEGROS 2 Senegaleses realizaron denuncia en el INADI por discriminación

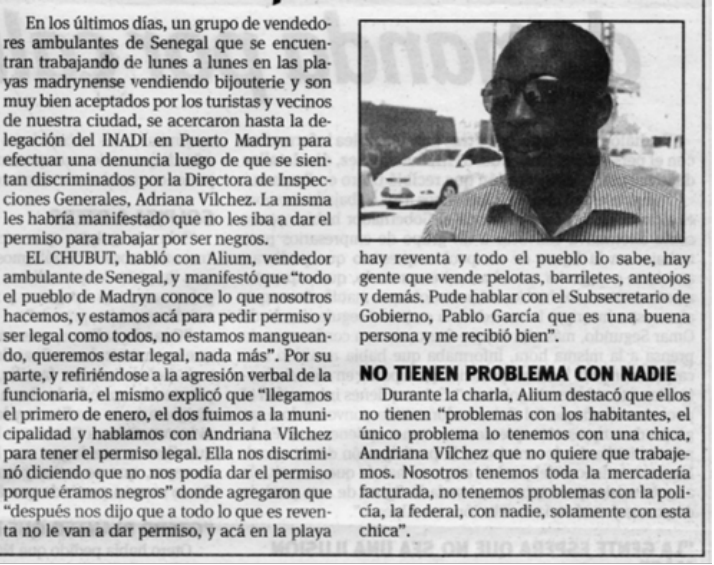

que "además "la bijouterie ${ }^{6}$ que venden estos señores no es bijou artesanal pero nosotros también tomamos la mirada del comerciante de

\section{"SIEMPRE TRANSGREDIERON NUESTRAS REGLAS"}

Vílchez aclaró que la prohibición de venta para los senegaleses es en la zona de la costa y que "el año pasado ya les habiamos dicho que no; siempre transgredieron nuestras reglas; yo lo que hago este año les digo directamente que no; que no pueden vender en la costa porque ya se les había dicho y ya se les había explicado; pueden vender en el sector de San Miguel porque sino pasamos a una situación de desigualdad; yo se los dije bien". 


\section{REFLEXIONES FINALES: ETNOFOTOGRAFIANDO CON COMERCIANTES SENEGALESES EN UNA CIUDAD PATAGÓNICA}

En este artículo abordé las prácticas laborales de migrantes de origen senegalés en Puerto Madryn, una ciudad de la Patagonia argentina, para contribuir desde los márgenes del conocimiento a la discusión sobre las negociaciones que se dan en las sociedades urbanas contemporáneas, problemática de estudio que tiende a estar sobrerrepresentada en las grandes ciudades latinoamericanas. Sin embargo, la diversidad sociocultural producto del aumento y diversificación de los flujos migratorios internacionales también se encuentra presente en el contexto de esta ciudad patagónica en expansión, y también aquí sus protagonistas son señalados como un problema que hay que gestionar.

Decidí abordar visualmente la problemática planteada como una apuesta teóricometodológica por abarcar la transversalidad y multidimensionalidad témporo-espacial de las experiencias migratorio-laborales de los senegaleses en el contexto urbano latinoamericano. Las representaciones imaginarias dominantes en la ciudad de destino me instaban a seguir este camino, mientras que algunas dimensiones de la cosmovisión nativa lo reafirmaban. Recurrí entonces a potenciar la dimensión sensible del método etnográfico para recoger otra capa de las experiencias sociales vividas, buscando transformar los datos sensibles obtenidos en el trabajo de campo en imágenes-objetos de conocimiento antropológico. Es así que las imágenes fueron utilizadas por su potencial para narrar visualmente, desde una la intertextualidad que repone la imagen y lo verbal/escrito como "cómplices necesarias" en la comprensión intelectual y la comunicación de resultados sobre el fenómeno humano.

Fue de este modo como busqué mostrar que Puerto Madryn -con su narrativa histórica particular, sus modos de concebirse a sí misma y a los migrantes africanos nuevos en este contexto- es el escenario de interacciones sociales atravesadas por contradicciones, conflictos y negociaciones, producto de las relaciones de fuerza que ejercen los diferentes grupos por la ocupación del espacio urbano, los cuales defienden o resisten los modelos dominantes de ciudad puestos en juego -industrial y de servicios y turismo. Esto acaba generando mecanismos de exclusión e hipervisibilización de la diferencia, para (re)establecer las jerarquías y distinciones que construyen un determinado imaginario de sociedad y territorio madrynense. Para el cual, las y los 
migrantes son sujetos ambiguos porque son marcados fenotípicamente y posicionados como lo desconocido y extraño -al constituir una minoría negra en un lugar "de/para blancos"- a la vez que los objetivan como un atractivo más que esta ciudad turística debe ofrecer y por eso les reservan una gestión diferencial.

Las narrativas dominantes en esta ciudad, obturan o buscan limitar la posibilidad de generación de "anomalías" en lo más material que tiene su ideal urbano, como es la calle y la playa. El "paseo costanero" se posiciona como el recurso más valorado y cotizado por el modelo de servicios y turístico de ciudad que cobra relevancia durante los meses de verano, siendo a la vez el espacio por antonomasia del comercio que protagonizan las y los migrantes senegaleses. Entonces, los recursos para combatir dichas "anomalías" socio-urbanas provienen también de sectores defensores de esa narrativa dominante de ciudad, que se pone en juego en el contexto de la temporada de verano. Y lo harán mediante estrategias para contener a los comerciantes de origen senegalés, las cuales articulan los controles desplegados por sus agentes estatales amparados en los códigos contravencionales, junto al tratamiento que le da su prensa dominante.

Pero el posicionamiento respecto de la presencia de las y los senegaleses muestra contradicciones. Por un lado, son un componente más de la oferta de atractivos acorde a los servicios que esta ciudad brinda a sus turistas cada verano, pero por otro lado, el aumento en la llegada de estos comerciantes aparece como una amenaza que pone al descubierto la laxitud de los controles municipales, y empiezan a considerarse como visitantes poco bienvenidos en el escenario visual costero prefigurado. Sin embargo, el poder institucional no se manifiesta con la violencia explícita encontrada en otras ciudades, sino mediante el juego de las negociaciones entre la prohibición y el permiso. Estrategias que, por ahora, les han funcionado a ambas partes, en tanto las y los migrantes senegaleses sostienen su venta durante la temporada, y la municipalidad (a veces junto a agentes de la policía, DNM y AFIP) da señales de hacer su trabajo y crea una sensación de mantenimiento del orden.

Estas señales tienen como aliado el periódico El Chubut, el cual acompaña también con un posicionamiento ambiguo, que tiende a la objetivación en torno al conflicto. Del componente "pintoresco" de la playa pasarán a estar asociados a significantes en torno al delito, sobre todo a partir de su exposición en una disputa 
mantenida con la inspección municipal en el marco una coyuntura general conflictiva de la ciudad.

Centrando la atención en la inmigración ilegal, los problemas de integración, crimen, violencia, terrorismo, retraso y, en general, propiedades negativas atribuidas a los otros, los discursos de las élites son así capaces de producir, difundir o confirmar los prejuicios e ideologías generalizados que, a su vez, dan lugar y legitiman la discriminación diaria en los campos de la inmigración, el mercado laboral, la vivienda, la política, la educación, la cultura, etc. (Van Dijk, 2006: 30).

Me permito finalizar con esta reflexión de Teun Van Dijk, como corolario de las narrativas presentadas en este artículo, en el cual busqué poner de relieve aquellos aspectos de los discursos dominantes en las complejas urbes contemporáneas, que configuran las dimensiones espaciales en las cuales se despliegan las trayectorias laborales de migrantes de origen senegalés en esta parte del mundo.

\section{REFERENCIAS}

ARANGO, Joaquín. Inmigración y diversidad humana. Una nueva era en las migraciones internacionales. Revista de Occidente, n. 268, 2003.

CAGGIANO, Sergio. Lo que no entra en el crisol. Inmigración boliviana, comunicación intercultural y procesos identitarios. Buenos Aires, Prometeo, 2005.

CLIFFORD, James. Itinerarios transculturales. España, Gedisa, 1999.

DIARIO EL CHUBUT. La Playa va tomando su habitual fisonomía en los primeros días de enero. Puerto Madryn, 4 de enero de 2013.

- Malestar entre un grupo de comerciantes por el traslado del

Paseo de los Artesanos. Puerto Madryn, 7 de enero de 2013.

. El verano en Puerto Madryn, Puerto Madryn, 11 de enero de

2012.

. Impresionante operativo en la playa por vendedores nigerianos.

Puerto Madryn, 20 de enero de 2014.

. Mónica Saso: "Hay que reunir pruebas para luego tomar la

denuncia”. Puerto Madryn, 22 de enero de 2014. 
. Inspectores municipales controlan a vendedores ambulantes en la playa. Puerto Madryn, 23 de enero de 2014.

. Operativo de la AFIP en la playa contra vendedores ambulantes senegaleses. Puerto Madryn: 24 de enero de 2015. Recuperado de: http://www.elchubut.com.ar/nota/78340/

. Adriana Vilchez: "Esta es una acusación totalmente falsa".

Puerto Madryn, 25 de enero de 2014. . Madryn: Hay que mantener la cordura para evitar un estallido.

Puerto Madryn, 26 de enero de 2014. Recuperado de: https://www.elchubut.com.ar/nota/2014-1-26-madryn-hay-que-mantener-la-cordurapara-evitar-un-estallido

Secuestran mercadería apócrifa durante operativo de control en el sector costero. Puerto Madryn, 20 de enero de 2016.

ESPIRO, María Luz. De Buenos Aires a la costa chubutense: una aproximación etnográfica a la movilidad estacional de migrantes senegaleses. En DE CRISTÓFORIS, Nadia; NOVICK, Susana (Comp.) Jornadas. Un siglo de migraciones en la Argentina contemporánea: 1914-2014. Buenos Aires, Universidad de Buenos Aires, 2016.

. Senegaleses entre Argentina y el sur de Brasil: etnografía de la movilidad regional y la alternancia laboral entre venta ambulante e industria. En MAFFIA Marta; ZUBRZYCKI, Bernarda (Coord.). Africanos y afrodescendientes en la Argentina: prácticas, representaciones, narrativas y memorias. Buenos Aires, Editorial Biblos, 2017.

. Trayectorias laborales de migrantes entre África y Latinoamérica: el caso de los senegaleses en argentina. REMHU, n. 56, 2019.

ESPIRO, María Luz; VOSCOBOINIK, Sonia; ZUBZYCKI, Bernarda. Enfrentando el racismo institucional. Análisis de dos casos de migrantes senegaleses en argentina (2012-2016). REMHU, n. 48, 2016.

FERRARI, Paula. Un lugar para vivir: la toma de tierras en el asentamiento informal Nueva Madryn, Patagonia argentina. Geografia em questão, v. 11, n. 2, 2018. 
GOLDBERG, Alejandro. Ser Inmigrante no es una enfermedad. Inmigración, condiciones de vida y de trabajo. El proceso de salud/enfermedad/atención de los migrantes. Tesis de Doctorado, Universitat Rovira I Virgili, Tarragona, 2003.

GRIMSON, Alejandro. Nuevas xenofobias, nuevas políticas étnicas en Argentina. En GRIMSON, Alejandro; JELIN, Elizabeth (Comps). Migraciones regionales hacia la Argentina. Diferencia, desigualdad y derechos. Buenos Aires, Prometeo, 2006.

GUBER, Rosana (Comp.) Prácticas Etnográficas. Buenos Aires, Miño y Dávila, 2014.

CLIFFORD, James. Itinerarios transculturales. España, Gedisa, 1999.

HALL, Stuart. Sin Garantías. Trayectorias y problemáticas en estudios culturales. Bogotá, Universidad Javeriana, 2010.

INDEC. Censo nacional de población, hogares y viviendas 2010: censo del Bicentenario: resultados definitivos, Serie $B n^{\circ}$ 2. Ciudad Autónoma de Buenos Aires, INDEC, 2012. Recuperado de: https://www.indec.gob.ar/ftp/cuadros/poblacion/censo2010_tomo2.pdf

KAMINKER, Sergio Andrés. Construcción de Comunidad: un 28 de julio en la ciudad de Puerto Madryn. Papeles del CEIC, v. 1, n. 105, 2014.

- Segregación residencial y proyectos de ciudad: Puerto Madryn como espacio en disputa. En VESSURI Hebe; BOCCO, G. (Coords.), Conocimiento, paisaje y territorio. Procesos de cambio individual y colectivo. Río Gallegos, UNAM, UNPA, UNRN, CENPAT-CONICET, 2015.

. Segregación Residencial en Puerto Madryn, Chubut (1991-2010) Formas y efectos de una urbanización acelerada en una ciudad intermedia de la Patagonia Central. Tesis de Doctorado, Instituto de Altos Estudios Sociales, Universidad Nacional de General San Martín, 2016.

MORALES, Orlando. G. Nuevas dinámicas migratorias globales y representaciones locales sobre los negros en Argentina. El caso de las percepciones de agentes de la Policía bonaerense sobre recientes migrantes africanos. Sociedad y discurso, n. 18, 2010 . 
- El racismo no es un problema de comunicación, sino de poder. Entrevista a Teun A. van Dijk. Revista Tram[p]as de la comunicación y la cultura, n. 70, 2012.

MUÑIZ TERRA, Leticia. Carreras y trayectorias laborales: una revisión crítica de las principales aproximaciones teórico-metodológicas para su abordaje. Revista Latinoamericana de Metodología de las Ciencias Sociales, v. 2, n. 1, 2012.

NARVAJA DE ARNOUX, Elvira. Análisis del discurso. Modos de abordar materiales de archivo. Buenos Aires, Santiago Arcos Editor, 2009.

PERELMAN, Marcela. Gramática de la vida y el trabajo en la calle. En PITA María. V.; PACECCA, María I. (Coords.). Territorios de control policial: gestión de ilegalismos en la Ciudad de Buenos Aires. Buenos Aires, EUFyL, 2017.

REITER, Paula. Dimensiones socioculturales de la migración senegalesa en Buenos Aires. VI Jornadas de Investigación en Antropología Social, Buenos Aires, 2010.

ROBERTI, Eugenia. Perspectivas sociológicas en el abordaje de las trayectorias: un análisis sobre los usos, significados y potencialidades de una aproximación controversial. Sociologias, Porto Alegre, v. 19, n. 45, 2017.

ROCHA, Ana. L. Carvalho da Antropologia das formas sensíveis: entre o visível e o invisível, a floração de símbolos. Horizontes Antropológicos, v. 1, n. 2, 1995.

ROCHA, Ana L. Carvalho da; ECKERT, Cornelia. Antropologia de e na cidade. Interpretações sobre as formas da vida urbana. Porto Alegre: Marcavisual, 2013. . Etnografia com imagens: práticas de restituição.

Tessituras, Pelotas, v. 2, n. 2, 2014. . A preeminência da imagen e do imaginário nos jogos da memoria coletiva em coleções etnográficas. Brasília, ABA, 2015.

RODRÍGUEZ, María G. Palimpsestos: mapas, territorios y representaciones mediáticas. Reflexiones Marginales, n. 10. 2011.

SASSONE, Susana; GONZÁLEZ, Myriam; MATOSSIAN, Brenda. Ciudades patagónicas de la Argentina: atracción, crecimiento y diversidad migratoria. Aristas (Mar del Plata). Revista de Estudios e Investigaciones, v. 5, n. 6, 2011. 
SEGURA, Ramiro. Vivir afuera: antropología de la experiencia urbana. San Martín: UNSAM Edita, 2015.

VAN DIJK, Teun. A. Discurso de las élites y racismo institucional. En BASTIDA, Manuel L. (Coord.). Medios de comunicación e inmigración. Murcia, CAM, 2006.

Recebido: $20 / 05 / 2020$

Aprovado: 04/09/2020 